
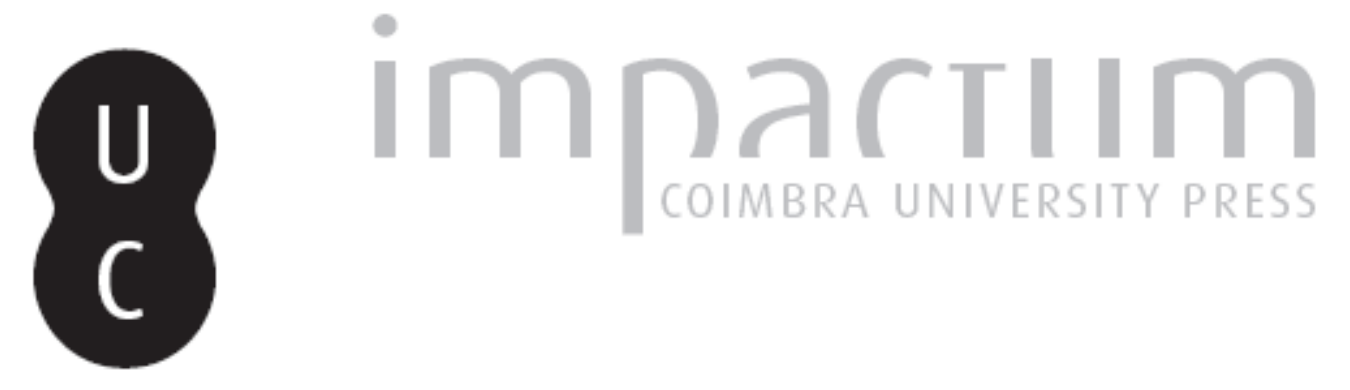

\title{
A taça romana de prata de Bracara Augusta
}

\section{Autor(es): $\quad$ Morais, Rui}

Publicado por: Faculdade de Letras da Universidade de Coimbra

URL persistente:

URI:http://hdl.handle.net/10316.2/37669

DOI:

DOI:http://dx.doi.org/10.14195/1647-8657_41_7

Accessed : $\quad$ 26-Apr-2023 03:11:02

A navegação consulta e descarregamento dos títulos inseridos nas Bibliotecas Digitais UC Digitalis, UC Pombalina e UC Impactum, pressupõem a aceitação plena e sem reservas dos Termos e Condições de Uso destas Bibliotecas Digitais, disponíveis em https://digitalis.uc.pt/pt-pt/termos.

Conforme exposto nos referidos Termos e Condições de Uso, o descarregamento de títulos de acesso restrito requer uma licença válida de autorização devendo o utilizador aceder ao(s) documento(s) a partir de um endereço de IP da instituição detentora da supramencionada licença.

Ao utilizador é apenas permitido o descarregamento para uso pessoal, pelo que o emprego do(s) título(s) descarregado(s) para outro fim, designadamente comercial, carece de autorização do respetivo autor ou editor da obra.

Na medida em que todas as obras da UC Digitalis se encontram protegidas pelo Código do Direito de Autor e Direitos Conexos e demais legislação aplicável, toda a cópia, parcial ou total, deste documento, nos casos em que é legalmente admitida, deverá conter ou fazer-se acompanhar por este aviso.

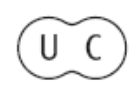




\section{CONIMBRIGA}

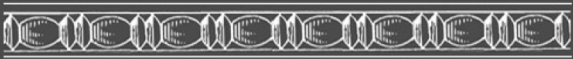

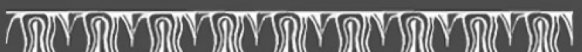
2

INSTITUTO DE ARQUEOLOGIA

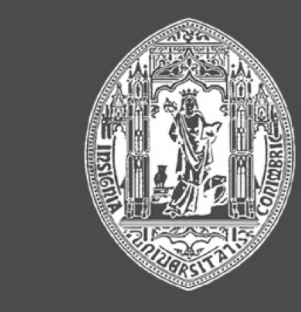

VOLUME XLI - 2002

F A C U L D A E D E LETRAS UNIVERSIDADE DE COIMBRA 
RUI MORAIS

Assistente da Universidade do Minho

A TAÇA ROMANA DE PRATA DE BRACARA AVGVSTA

"Conimbriga" XLI (2002) p. 165-180

RESUMO: Estuda-se uma taça romana em prata, com incrustações de ouro e niello, de elevado interesse artístico encontrada no conjunto termal do Alto da Cividade (Braga).

Apresenta-se o seu contexto estratigráfico; analisa-se o seu repertório figurativo e propõe-se uma cronologia augustana de acordo com outros testemunhos conhecidos para aquele período. Propõe-se ainda uma provável origem na região da Campânia.

Por fim, propõe-se a sua tecnologia de fabrico e apresenta-se um pequeno apêndice sobre o uso do niello desde a antiguidade até à época moderna.

SUMmARY: A Roman silver cup, encrusted with gold and black enamel, of great artistic interest, found at the bath complex at Alto da Cividade (Braga), is studied.

Its stratigraphic context is presented as well as its figurative repertoire and an Augustan chronology is suggested taking in account other known examples for that period. It is also suggested that the present piece was probably made in Campania.

Finally, its manufacturing technique is proposed and a short appendix on the use of the black enamel from the ancient world up to the modern age is presented. 
(Página deixada propositadamente em branco) 


\section{A TAÇA ROMANA DE PRATA DE BRACARA AVGVSTA}

As escavações realizadas em Braga, no âmbito do "Projecto de Salvamento de Bracara Augusta", têm dado testemunhos significativos da presença romana nesta cidade. Entre estes, merece lugar de destaque uma magnífica taça em prata, com incrustações de ouro e niello, de elevado interesse artístico, e que é objecto deste estudo (Fig. I; Est. I, 1 e 2).

Encontrada na insula $\mathrm{V}$ do conjunto termal do Alto da Cividade, e actualmente em depósito no Museu D. Diogo de Sousa (Braga, n. ${ }^{\circ}$ inventário: 1991.0695), esta peça é de extrema raridade entre o espólio romano aparecido em Portugal - o que é explicável pelo facto de a quase totalidade destas peças ter sido fundida em época romana e em momentos posteriores.

\section{Contexto estratigráfico:}

Esta sondagem tem as dimensões de $3 \times 2,5 \mathrm{~m}$, situando-se a NO.

As escavações do local foram realizadas no ano de 1979 permitindo identificar o limite do muro M2, de óptimo aparelho e regular, que viria a ser interpretado como pertencente ao $1 .^{\mathrm{o}}$ projecto das Termas.

Na sua parte este o M2 faz um ângulo com o M1 (muro estrutural do edifício pré-termal e termal) e com o M9 (muro estrutural do edifício termal), delimitando assim uma área de serviços subterrânea das termas, sobre a qual existiam lojas ao nível da rua norte.

A leitura estratigráfica do perfil sul da sondagem $\mathrm{T} 16 \mathrm{~A}$ permite contextualizar a peça em estudo como sendo proveniente de uma camada (02) de enchimento, sob uma camada de derrube (01), e, por sua vez, sobre níveis de enchimento e nivelamento sobre a rocha (03 e 05) associados a uma ocupação pré-termal da zona (Fig. 2).

Embora tenhamos proposto para a peça em estudo uma datação augustana, o facto de se encontar associada a uma lucerna datável da 
$2^{\mathrm{a}}$ metade do séc. I/ $1^{\mathrm{a}}$ metade do séc. II sugere a sua utilização, pelo menos, durante todo o séc. I, podendo o seu enterramento ser datado do período que corresponde à adaptação do edifício pré-termal a complexo balnear público, datado com grande probabilidade dos inícios do séc. II $^{1}$ (Fig. 3). baixo:

A leitura estratigráfica do perfil sul é a seguinte, de cima para

c. 00 e 01 - terra fina compacta, coloração castanha clara com manchas acinzentadas à mistura. Contém bastante material, tipo médio e grosseiro, essencialmente granito (também possui tijoleira). Contém, ainda, um ou outro carvão disperso. Camada de derrube.

c. 02 - terra fina pouco compacta. Coloração cinzenta. Contém um ou outro pequeno elemento de granito e tegulae. Inúmeros pequenos fragmentos de carvão disperso. Nível de incêndio.

c. 03 - terra fina e compacta de coloração cinzenta saibrosa. Contém material de tipo fino e médio de granito e tegulae. Nível de enchimento.

c. 04 - terra fina pouco compacta. Coloração negra. Contém um ou outro pequeno elemento de granito, tegulae e quartzo. Inúmeros pequenos pontos de carvão disperso.

c. 05 - terra fina pouco compacta. Coloração bege (alterite). Contém um ou outro pequeno elemento de granito. Enchimento sobre a rocha.

c. 06 - terra fina, pouco compacta, coloração cinzenta-escura. Contém pequenas manchas de areia fina à mistura. Contém, ainda, material de tipo fino e médio de granito e tegulae. Pequenos pontos de carvão disperso.

c. $06 \mathrm{~A}$ - equivalente à 06 com manchas de argamassa alaranjada, sendo o material mais grosseiro.

c. 06B - equivalente à 06 com maior concentração de carvões (material grosseiro tipo granito).

c. $06 \mathrm{C}$ - equivalente à 06 sendo a sua coloração mais acastanhada e pequenas manchas de areia fina pouco consistente.

1 O facto desta peça ter sido encontrada num canto extremo do edifício, associada a uma lucerna em bom estado de conservação, poderá ser indicativo de um ocultamento. Tratando-se ou não de um ocultamento, não deixa, porém, de ser significativo o facto desta peça provir de um contexto cronológico coincidente com aqueles conhecidos para os tesouros oriundos de outros centros urbanos do Noroeste, datáveis, na sua grande maioria, dos finais do século I e do século II (Centeno, 1987: 275). Sabemos ainda que, no caso das peças em prata, o entesouramento foi preponderante até ao início da dinastia dos Antoninos (designadamente até ao reinado de Adriano, id., ibidem.: 282), decorrente de uma possível valorização deste metal relativamente ao ouro (id., ibidem: 282). 
Ainda que especialmente difundidas a partir do período augustano, estas peças estavam presentes em todos os domínios da vida quotidiana, com especial destaque para as usadas como baixela de mesa, como testemunham, entre outros, os tesouros provenientes da uilla rústica de Boscoreale (Baratte, 1973: 45; Zanker, 1992: 268-270) e da Casa de Menandro em Pompeia (Baratte, 1973: 45). Por vezes, uma taça, como esta que apareceu em Braga, constituía todo o capital de uma pessoa modesta, soldado ou pequeno comerciante, mudando frequentemente de proprietário, como se depreende dos vasos decorados com folhas de oliveira provenientes do tesouro de Boscoreale que possuem no pé o nome de três proprietários sucessivos (id., ibidem).

A riqueza decorativa desta taça não deve, porém, fazer esquecer que este género de materiais era realmente usado, se não quotidianamente, pelo menos nos grandes banquetes, quer em Roma, quer em cidades de província como Bracara Augusta. Tal situação depreende-se, aliás, da parábola de "O Satíricon", de Petrónio, quando o liberto imperial com origem oriental, chamado Trimalquião, proclama que as pratas são a sua grande paixão (52). A comprová-lo temos a existência de dois tesouros da época augustana: um encontrado em 1868 em Hildesheim, na Saxónia (Alemanha), actualmente em depósito no Staatliche Museum (Berlim), que demonstra como grandes quantidades de objectos de prata eram levados pelos seus proprietários para as províncias; e um outro, longe das fronteiras do Império, documentado numa rica sepultura em Hoby, na Dinamarca, pertencente a um dos grandes chefes das tribos da Europa setentrional (Bandinelli, 1992: 204; Painter, 1997: 21-22).

Saliente-se que, no mundo romano, o sucesso de baixelas de prata se deve, inicialmente, à presença de oficinas gregas orientais, pelo menos desde 300 a. C., como parece testemunhar o importante número de kylikes provenientes de Montefortino (Metropolitan Museum of Art, Nova Iorque) e de Boscoreale, na Itália (British Museum, Londres), e de Paternò, na Silícia (Staatliche Museum, Berlim) (Painter, 1997: 17). Mas é, sobretudo, a partir de 200 a. C. que os Romanos se tornam grandes coleccionadores de baixelas de prata produzidas no mundo grego oriental, nessa altura destinado a abastecer o mercado romano. É então que o estilo "Helenístico" se funde completamente com o "Romano", dando início à chamada escola neo-Ática que, inicialmente estimulada pelo influxo de acontecimentos militares, surge agora como 
resposta à procura romana de trabalhos de arte decorativa em estilo grego (id.: 22-23). No entanto, apesar destes começos auspiciosos, a época áurea da torêutica romana apenas se faz anunciar entre os finais da República e os inícios do Império (entre Sila e os Flávios) sob o influxo directo de artistas gregos que estabeleceram as suas oficinas na Itália meridional (Pappalardo, 1989: 94; 97).

Se observarmos cuidadosamente o repertório figurativo da peça em estudo, apercebemo-nos de que aquilo que poderia parecer exclusivamente ornamental possui, na realidade, um significado simbólico:

- os motivos de bucrânios e grinaldas incrustados a ouro na parte superior da parede externa da peça são de típica inspiração helenística (Est. II). Usados com fins decorativos ou religiosos pela escola neo-Ática, que se desenvolve em Atenas ao longo de todo o séc. I a. C. (id., ibidem), estes motivos passaram, na época do Principado de Augusto, a representar signos alusivos à sua propaganda política, onde praticamente não existe nenhum monumento ou edifício em cuja decoração não se achem caveiras de animais sacrificados com motivos de grinaldas entrelaçadas (Bandinelli, 1992: 188; Zanker, 1992: 146-7) (Est. III, 1 e 2) inclusivamente, em contextos que não tinham em absoluto um carácter sagrado (id., 146). É, assim, possível cotejar este tipo de motivos com aqueles que se encontram em relevos de terracota (Coarelli, 1984: 130-131) (Est. IV), em relevos de estuque (Est. V), em trípodes de bronze (Est. VI), em moedas (Est. VII, 1) e em algumas decorações de terra sigillata itálica que, como sabemos, procuravam copiar as baixelas de metal (Oswald e Pryce, 1966: 4, Pl. II, n. ${ }^{\circ}$ 1) (Est. VII, 2). No entanto, torna-se mais evidente este paralelo se recorrermos à análise de uma das oinochoe de prata, proveniente da villa rústica de Boscoreale, na qual se encontra uma pequena faixa decorada com linhas de pérolas, bucrânios e grinaldas idênticas às utilizadas na taça em estudo (Ests. VIII e IX).

- as flores e as aves incrustadas na parte inferior têm um significado simbólico muito importante, para além do seu valor decorativo, ao procurarem representar a abundância e a fertilidade de uma nova Era (Est. I, 1 e 2). Devemos considerar, ainda, a proximidade de parentesco existente entre os elementos empregues nesta taça e o repertório decorativo das pinturas murais e dos mosaicos, com motivos nilóticos, encontrados em Pompeia (Martin, Bandinelli, Moreno, Coarelli e Torelli, 1985: 507-508; Fig. 61b, XVIII) (Est. X, 1 e 2). 
- a faixa central, delimitada pelas anteriores decorações fito-zoomórficas, é profusamente decorada com incrustações em ouro figurando palmetas estilizadas e arqueadas para fora das semi-folhas de acanto, que se evidenciam e contrastam num fundo negro em niello (Est. I, 1 e 2). Estes motivos, bem conhecidos para o mundo romano, encontram-se, particularmente, bem representados nas pinturas murais de Pompeia (Riegl, 1980: 185) (Est. XI, 1) e nos relevos de terracota (cfr. Garcia y Bellido, 1979: 214-216; figs. 310-315), que caracterizam um gosto helenístico de tendência neo-Ática. Esta decoração pode ser também encontrada numa taça de prata proveniente de Boscoreale (Est. XI, 2; Est. XII, 1 e 2), e numa oinochoe de bronze encontrada em Vila Marim que possui a típica decoração do kimátion lésbico (Almeida, 1972: 5-13) (Est. XIII; Est. XIV; Est. XV, 1 e 2).

Sob o ponto de vista da execução, esta taça testemunha o alto nível artístico das oficinas de ourivesaria romana, revelando ainda uma grande qualidade técnica e um gosto decorativo assaz seguro, que une a habilidade do trabalho do metal ao uso discreto do dourado.

A utilização de elementos típicos do repertório da arte menor nilótica, como sejam as flores e as aves, leva-nos a crer que estamos perante uma obra de um ourives grego proveniente de Alexandria que trabalhou em Itália, em Roma, por exemplo, ou numa cidade da Campânia, na mais pura tradição greco-romana ${ }^{2}$. No entanto, e apesar de, no estado actual dos nossos conhecimentos, ser impossível distinguir a personalidade estilística destas duas regiões, propomos, para a peça em estudo, uma provável origem na região da Campânia. Esta proposta leva em consideração a quantidade de utensílios e vasos de bronze e prata provenientes desta região, que, como sabemos, ocupava uma posição chave na importação de metais, através do porto de Putéolos, nos finais da República e inícios do Império, e tinha, na cidade de Cápua, um centro declarado da produção de bronzes (Kunzl, 1981: 12; Pappalardo, 1989: 98). E, também aqui, há que contar com o facto de, naquela época, as oficinas de ourivesaria pertencerem, na sua quase totalidade,

2 Excluída está a possibilidade de se tratar de uma obra de produção peninsular. De facto, não deixa de ser interessante verificar que, nesta torêutica, não se identifica nenhuma forma similar, nem de igual qualidade técnica e artística (cf. Bandera Romero, 1996: 601-702; Raddatz, 1969). 
a artistas gregos, cuja produção não seria inferior à da própria cidade de Roma (Pappalardo, 1989: 94; 97).

Os motivos decorativos representados por bucrânios e grinaldas, provavelmente inspirados em trabalhos oficiais, indicam que estamos perante uma obra do período de Augusto e que, à semelhança das taças históricas de Boscoreale, também esta poderá ter pertencido a uma classe de objectos relacionados com a corte imperial e sua propaganda política.

Permanece, no entanto, em dúvida o tipo de uso a que se destinou este objecto. Tratar-se-ia de uma taça usada com fins sacerdotais ou, tão somente, usufruída por um habitante abastado da cidade para as ofertas de grão e de sal aos Penates no culto doméstico?

\section{DESCRIÇÃO DA PEÇA}

\section{DESCRIÇÃO FORMAL}

Pequena taça ${ }^{3}$. Parede com perfil côncavo, rectilínea a cerca da sua metade, terminando num bordo simples, ligeiramente esvasado; possui na face externa três faixas decoradas, separadas entre si por linhas de pérolas que as demarcam. Termina num baixo pé, redondo e anelar.

\section{PESO E DIMENSÕES:}

Peso: 242 gr.

Dimensões: Larg. máx. do pé: $0,5 \mathrm{~cm}$; alt. do pé: $0,5 \mathrm{~cm}$; diâm. da base: $4,7 \mathrm{~cm}$; alt. da taça: $3,1 \mathrm{~cm}$; larg. das pérolas: $0,5 \mathrm{~mm}$; alt. de cada facha decorada a partir das pérolas: $0,6 \mathrm{~cm}$.

\section{CONSTITUINTES DA LIGA METÁLICA E DA DECORAÇÃO:}

Constituintes da liga metálica: prata em cerca de $99 \%$.

Constituintes da decoração: ouro. Faltam alguns motivos florais dispersos, três patos e cerca de $1 / 4$ destacado do suporte. A faixa decorativa central contrasta num fundo negro constituído por niello (esmalte negro). Tratar-se-á da aplicação da receita transmitida por Plínio?

\section{APRESENTAÇÃO SUMÁRIA DA TECNOLOGIA DE FABRICO:}

Fase I: Elaboração do molde.

Provável produção a partir de um modelo de cera perdida. A regularidade da peça leva a supor que esta tenha sido trabalhada no torno.

${ }^{3} \mathrm{Na}$ bibliografia consultada não encontramos paralelos formais para esta pequena taça de prata. 
Fase II: Trabalho no torno.

Da análise efectuada à lupa binocular, depreende-se que esta peça teria sido, depois de fundida, trabalhada no torno. Dessa análise evidencia-se:

- um visível esmagamento, resultante, provavelmente, do movimento de rotação da peça apoiada no ponto do torno (Est. XIV, 1 e 2);

- a existência no interior da base da peça de um cunho em ouro que poderá corresponder não apenas a uma mera função decorativa, mas também à função de tapar a marca provocada pela fixação da peça no torno (Est. XVII, 1);

- os frisos que separam as três faixas decoradas teriam sido torneados e na faixa central cavadas reentrâncias para a fixação do niello (Est. XVII, 2).

Fase III: Acabamentos finais: as decorações.

A análise à lupa binocular permitiu ainda verificar:

- a punção das pérolas executadas sobre os frisos (Est. XVIII, 1);

- a gravação e desenho das decorações por cinzelagem (Est. XVIII, 2);

- a colocação dos motivos decorativos embutidos em ouro pelo processo da placagem (neste caso, cavando depressões na superfície da peça para aí inserir os embutidos em ouro, os quais, posteriormente, seriam martelados e fechados). A fixação destas decorações terá beneficiado, todavia, da prévia execução de uma superfície desbastada e rugosa (por extracção ou percussão?) (Est. XIX, 1 e 2);

- a aplicação das decorações centrais em ouro depois do alisamento e polimento da faixa central em niello (Est. XX, 1).

\section{DESCRIÇÃO DA LUCERNA}

Fabrico: Local (Fig. 4).

Tipo: afim a Bailey C (iv).

Cronologia: $2^{\underline{a}}$ metade do séc. I / $1^{\underline{a}}$ metade do séc. $\mathrm{II}^{4}$.

4 As lucernas de bico redondo e volutas duplas depressa teriam sido suplantadas pelas séries de bico redondo sem volutas, de grande sucesso. Pondo de parte a discussão sobre a data precisa do começo da sua produção, é geralmente aceite e comprovado o seu aparecimento por volta dos meados do séc. I, mantendo-se até finais deste século ou mesmo permanecendo durante a $1^{\underline{a}}$ metade do séc. II. As lucernas do tipo Bailey (iv), mais pesadas, com a orla larga e lisa e o bico volumoso, devem ter 
Paralelos: Lucerna n. ${ }^{\circ} 42$ achada ocasionalmente numa vala aberta para implantação dos alicerces para a construção das casas n. ${ }^{\circ}$ 682-706 da Avenida Marechal Gomes da Costa (actual Avenida da Liberdade) (Sousa, 1966, n. ${ }^{\circ}$ 7, Est. IV, 172-173; Delgado, 1989-90, fig. 41, n. ${ }^{\circ} 42$, 170, 172 e 180 - Via XVII).

Proveniência: BRA 79 T 16A.

Posição estratigráfica: c. 02.

N. ${ }^{\circ}$ de inventário: M.D.D.S. 1991.1526.

\section{CATÁlOGO DAS ESTAMPAS}

EsT. I

1 e 2. Taça romana, em prata, de Bracara Augusta. Fotografia.

EST. II

Pyxis de prata proveniente de Palaiokastron, Grécia, c. de 100 a. C.. Forma cilíndrica com o corpo decorado com figuras de ménades dançantes em alto relevo e testo piramidal com a representação de grinaldas de frutos sustentadas por máscaras de teatro e bucrânios. Museu Arqueológico Nacional. Atenas.

\section{EsT. III}

1. Pedestal de mármore de uma estátua, proveniente de um pequeno santuário de Hércules. Os ramos e o bucrânio evocam o rito do sacrifício. Roma.

2. Ara Pacis Augustae, 13-9 a.C.. Lado interior dos paramentos de mármore do altar. Decoração com grinaldas, bucrânios, fitas e páteras. Roma.

\section{EsT. IV}

Lastra de terracota proveniente da zona do Templo de Apolo. Representação de Atena, de Perseu e da cabeça de Medusa. O friso inferior possui uma decoração com bucrânios, grinaldas e páteras. Antiquário do Palatino. Roma.

começado a ser fabricadas à roda de 75/80 e terminado já no tempo de Adriano, a julgar por uma lucerna deste tipo encontrada numa sepultura de Tipasa juntamente com uma moeda daquele imperador. A decoração do disco com folha de palma em posição normal ou invertida é muito frequente em lucernas deste ou de outros tipos desde o começo da $2^{\text {a }}$ metade do séc. I e durante o séc. II. 
EST. V

Relevo de estuque do apodyterium das Termas de Pompeia.

EsT. VI

Trípode de um braseiro romano em bronze, proveniente de Pompeia. Museu Nacional. Nápoles.

EST. VII

1. Aureo, cunhado em 17 d. C. por ocasião dos ludi saeculares: candelabro circundado por páteras e bucrânios.

2. Cálice em terra sigillata itálica. Forma II, Haltern. Decoração com representação de bucrânios, páteras e grinaldas.

EST. VIII

Oinochoe proveniente do tesouro augustano de Boscoreale, cujo tema central está representado por uma Vitória a degolar um touro. Museu do Louvre. Paris.

Est. IX

Id. Pormenor da pequena faixa decorada com linhas de pérolas, bucrânios e grinaldas idênticas à peça de Braga.

EsT. X

1. Fauna nilótica, pormenor do mosaico pavimental da Casa do Fauno em Pompeia. Museu Nacional. Nápoles.

2. Mosaico proveniente da Casa do Fauno em Pompeia. Museu Nacional. Nápoles.

EsT. XI

1. Ornamentos de pinturas murais pompeianas com a representação de palmetas estilizadas.

2. Taça proveniente do tesouro augustano de Boscoreale cujo tema central está representado por grous e cegonhas. Museu do Louvre. Paris.

EsT. XII

1. Id. Desenho.

2. Id. Pormenor da decoração sobre a moldura do pé com a representação de palmetas estilizadas.

EsT. XIII

Oinochoe romano, em bronze, de Vila Marim. Vila Real. Fotografia. 
EsT. XIV

Id. Desenho.

EsT. XV

1. Id. Pormenor da decoração presente na transição do colo com a pança. Linha de pérolas donde saem folhas cordiformes, havendo entre cada uma destas um motivo vegetal de tríplice folha.

2. Id. Pormenor com a mesma decoração sobre a moldura do pé.

Est. XVI a XX-1

Pormenores da tecnologia de fabrico.

EsT. XX-2

Phiale em prata com incrustrações em ouro e niello de bucrânios, arcos e rosetas (1400-1300 a.C.). Nicosia. Museu de Chipre.

Est. XXI

1. Taça de três pés proveniente do tesouro de Hildelsheim: decoração cinzelada em forma de folhas de loureiro com incrustação de niello.

2. Taças decoradas com folhagem de hera proveniente do mesmo tesouro com incrustação de niello.

\section{APÊNDICE: O NIELLO}

O niello é uma técnica que tem a sua origem nas civilizações antigas orientais. Não se conhece, no entanto, para o mundo antigo, uma descrição do processo de fabrico e sua aplicação; apenas Plínio (História Natural, Livro XXXIII, 131) diz que os egípcios misturavam 1 parte de prata e $2 / 3$ de 1 parte de cobre com enxofre, mas não refere o procedimento. Testemunhada, ainda, no período da Civilização Micénica ${ }^{5}$ (Est. $\mathrm{XX}, 2$ ), esta técnica terá sido depois esquecida, para apenas reaparecer mais tarde no período Romano ${ }^{6}$. Aqui, conhecida pelo menos a partir dos finais da República, como comprovam, entre outros, os exemplos provenientes do tesouro de Hildesheim (Est. XXI, 1 e 2), torna-se corrente no período Imperial e conhece um vivo sucesso no séc. IV, quer

5 Os melhores exemplos desta técnica provêm dos "Shaft Graves" em Micenas e Routsi (Iakovides, 1994: 225).

${ }^{6}$ Greek Jewellery - 5000 years of tradiction (s/data). Greek Jewellery - 5000 years of tradiction [em linha], p. 32.

$<$ http://www.addgr.com/jewel/elka/page32.htm> [Consulta: 16 Agosto 2000]. 
em motivos geométricos simples e repetitivos, quer em grandes composições figuradas (Kunzl, 1981: 50; Painter, 1997: 31). Particularmente utilizada nas baixelas de prata, com decorações que variam desde o preenchimento de simples inscrições até desenhos muito complexos, foi ainda utilizada na decoração de bijutarias e de equipamentos militares, em ligas de cobre e sobre o ouro (Hughes, Lang, La Niece e Oddy, 1989: 27).

Depois da época romana, a técnica do niello foi largamente utilizada em peças de joalharia bizantina e, na Europa, até à época renascentista. $\mathrm{Na}$ Idade Média esta técnica foi utilizada por ourives que trabalhavam na dependência de um monarca ou ao serviço de um mosteiro (Lightbown, 1997: 46). A crescente popularidade do niello é, todavia, uma característica dos trabalhos realizados no séc. XIII: o período foi de grande sofisticação artística e, nele, o trabalho em niello parece ter sido particularmente apreciado em todo o ocidente da Europa. No século seguinte dá-se um declínio evidente na utilização desta técnica, com a excepção de Itália (anunciando a sua aplicação ainda no séc. XV) e, a Norte de Europa, da Rússia, à qual, desde então, passará a estar associada (id., 56-57). Conhecida em Kiev, nos sécs. XII e XIII, e profusamente utilizada na Rússia, nos sécs. XVI e XVII, esta técnica foi característica do Período Imperial, em particular na cidade de Moscovo e em alguns centros provinciais. ${ }^{7}$ Neste contexto, a cidade de Moscovo, reduzida a centro provincial depois da côrte se ter mudado para S. Petersburgo, passará no séc. XVIII a ser o centro do trabalho do niello e a ter na figura de Alexey Ratkov um dos seus maiores representantes (Barr, 1997: 153; Bury, 1997: 188).

No que diz respeito à sua constituição, sabemos que, no mundo romano, o niello tinha como composto principal o mesmo metal que o objecto que decorava (sulfureto de prata sobre prata, cobre sobre bronze ou sobre latão), o que sugere que se tinha o hábito de o preparar a partir de um metal de refugo na mesma oficina em que se fabricava o objecto a decorar (Hughes, Lang, La Niece e Oddy, 1989: 27).

Num estudo realizado sobre o niello, A. Moss (1953: 49-52) verificou, através da análise de 19 peças, que até aos sécs. X-XI este corresponde ao mineral alcantite (sulfureto de prata). Alvitra ainda (id., ibidem) que o processo mais simples de obter niello antes dos sécs. X-XII (altura em que Theophilus terá descoberto a receita que permitia trabalhar este produto em estado de fusão) consistia em encher as cavidades com o pó,

${ }^{7}$ Hillwood Museum \& Gardens Art Collections (s/data: Washington D. C., USA). Hillwood Museum \& Gardens [em linha]: Art Collections, Washington, USA. $<\underline{\text { http://www.hillwoodmuseum.org/art-collection/metal/niello.html }>\text { [Consulta: } 16}$ Agosto 2000]. 
aquecer a prata localmente e, logo que ele desse início a uma massa plástica, alisá-la com uma espátula metálica até uniformizar a pasta que finalmente seria polida.

A partir do sécs. X-XI, o niello corresponde a uma mistura de sulfuretos de prata e cobre (stromererite) a que, na maior parte dos casos, se junta sulfureto de chumbo (galena). Esta mistura funde a temperaturas baixas (cerca de $440 .^{\circ}$ ) para a proporção 5 (sulfureto de prata), 7 (sulfureto de cobre), 8 (sulfureto de chumbo), sem lugar a decomposição (id., ibidem).

\section{BIBLIOGRAFIA}

AlmeIDA 1972 = C. A. F. AlmeIDA - O “Oenokoé”, romano, em bronze, de Vila Marim, Universidade Portucalense, Porto, 1972, 5-13.

BANDERA RoMero 1996 = Ma L. BANDERA ROMERO - "Objectos de plata que acompañan a las tesaurizaciones”, in: CHAVES TRISTÁN, F., Los tesoros en el sur de Hispania. Conjuntos de denarios y objectos de plata durante los siglos II y I a. C., Fundación Almonte, Sevilha, 1996, 601-702.

BANDINELLI 1992 = R. B. BANDINELLI - Roma. L'arte romana nel centro del potere. Dalle origini alla fine del II secolo d. C..", Biblioteca Universale Rizzoli, Bur Arte, Milão, 1992.

BARATTE 1973 = F. BARATTE - "Un trésor d'argenterie du début de l'Empire. La trouvaille de Boscoreale", Archeologia, Paris, 1973, 44-49.

1979 = "La coupe aux poisson du musée du Louvre", La revue du Louvre, I, 1979, 6-14.

1980 = "Le trésor d'orfèvrerie gallo-romaine de Reims", Gallia, tomo 38, fasc. 2 , 1980, 253-264.

1981 = "Le Trésor d'Argenterie Gallo-Romaine de Notre-Dame-D'Allençon (Maine-et-Loire)", Xle supplément à Centre National de la Recherche Scientifique, Paris, 1981.

1981 = "La vaisselle d'argent en Gaule", Les Dossiers. Histoire et archéologie, n. ${ }^{\circ} 54$ / Juin, Dijon, 1981, 38-51.

1984 = "A propos d'une coupe en argent trouvée en Gaule: remarques sur une technique particulière dans l'orfèvrerie romaine", Revue du Nord, tome LXVI, n. ${ }^{\circ} 260,1984,221-230$.

Centeno 1987 = Rui M. S. Centeno - "Circulação Monetária no Noroeste da Hispânia até 192”, Anexos Nvmmvs, n. ${ }^{\circ}$ 1, Dissertação de Doutoramento em Pré-História e Arqueologia, Porto, 1987.

Coarelli 1984 = F. CoArelli - "Roma Sepolta", Biblioteca di Archeologia, Curcio, Milão, 1984.

Dosi e SCHNELl 1986 = A. Dosi e F. SCHNELL - "Vita e costumi dei romani antichi. 2. Pasti e vasellame da tavola”, Museo della Civiltà Romana, Edizione Quasar, Roma, 1986. 
Garcia y Bellido 1979 = A. GARCIA y Bellido - "Arte Romano", Enciclopedia Clasica, n. $^{\circ}$ 1, Madrid, 1979.

Gehrig 1981 = U. Gehrig - "Le trésor d'Hildesheim", Les Dossiers. Histoire et archéologie, n. ${ }^{\circ} 54$ / Juin, Dijon, 1981, 22-37.

Hughes, Lang, la Niece e Oddy $1989=$ M. Hughes, J. Lang, S. LA Niece e A. Oddy - "Technologie de l'argenterie romaine", Éditions de la Réunion des musées nationaux, Paris, 1989, 21-28.

IAKOVIDES 1994 - Spyros IAKOVIDES - "Mycenaean Art", Greek Art. The Dawn of Greek Art, Ekdotike Athenon, Atenas, 1994, 219-291.

JOHANSEN $1960=$ K. F. JOHANSEN - "New evidence about the Hoby silver cups", Acta Archaeologica, vol. XXXI, fasc. 2-3, 1960, 185-190.

KunZL 1981 = E. KunZL - "Les riches decors en relief de l'argenterie de Pompei", Les Dossiers. Histoire et archéologie, $\mathrm{n}^{\circ} 54$ / Juin, Dijon, 1981, 10-21.

MARTIN-KILCHER 1989 = S. MARTIN-KILCHER - "Services de table en métal précieux du 1er au 5e siècle", Éditions de la Réunion des musées nationaux, Paris, 1989, 15-20.

Martin, Bandinelli, Moreno, Coarelli e Torelli $1981=$ R. Martin, R. B. BandiNelli, P. Moreno, F. CoArelli e M. ToRelli - "La cultura ellenistica. Le arti figurative, Storia e civiltà dei Greci, 10, Bompiani, Milão, 1981.

Moss 1953 = A. A. Moss - "Niello", Studies in Conservation, I, 1953, 49-52.

PAINTER 1989 = K. PAINTER - "Les collections d'argenterie gallo-romaine au British Museum", Éditions de la Réunion des musées nationaux, Paris, 1989, 13-14.

PAPPALARDo 1989 = U. PAPPALARDo - "Gli argenti”, Le Collezioni del Museo Nazionale di Napoli, De Luca Edizioni d'Arte Leonardo, Roma, 1989, 91-101.

PetróNIO - O Satíricon, (trad.) Jorge de Sampaio, Edições Europa-América, Mem Martins, 1973.

Pfrommer 1983 = M. Pfrommer - "Griechische Originale und Kopien unter romischem Tafelsilber". The J. Paul Getty Museum Journal", vol. 11, 1983, 135-146.

Pline L'ANCIEN - Histoire Naturelle, Livre XXXIII (trad.) Hubert Zehnacker, Societé D`édition “Les Belles Lettres”, Paris, 1983, 100-101, 219.

OLIVER 1981 = A. OLIVER - "L'argenterie d'Epoque Republicaine dans les collections Americaines", Les Dossiers. Histoire et archéologie, n. ${ }^{\circ} 54$ / Juin, Dijon, 1981, 52-63.

Oswald e PRYce 1966 = F. Oswald e T. D. PRYCE - An Introduction to the study of Terra Sigillata, Gregg Press LTD. London, 1966.

RADDATZ 1969 = K. RADDATZ - "Die Schatzfunde der Iberischen Halbinsel vom ende des dritten bis zur mite der ersten Jahrhunderst von Chr. Geb. Untersuchungen zur hispanischemn Toreutik", Madrider Forschungen, 5, Berlim, 1969.

RIEGL $1980=$ A. RIEGL - Problemas de estilo. Fundamentos para una historia de la ordenación, G G Arte, Barcelona, 1980.

TASSINARI 1993 = S. TAssinari - Il Vasellame Bronzeo di Pompei, Cataloghi 5* e 5 **, "L'Erma de Bretschneider, Roma, 1993.

VAN DE GRIFT 1984 = J. VAN DE GRIFT - "Tears and Revel: The Allegory of the Berthouville Centaur Scyphi”, American Journal of Archaeology (A. J. A.), vol. 88, n. ${ }^{\circ}$ 3, July, 1984, 377-388. 
ZANKer 1992 = P. ZANKer, P. - Augusto y el poder de las imágenes, Alianza Forma, Madrid, 1992.

Hillwood Museum \& Gardens Art Collections (s/data: Washington D. C., USA). Hillwood Museum \& Gardens [em linha]: Art Collections, Washington, USA. $<$ http://www.hillwoodmuseum.org/art-collection/metal/niello.html $>$ [Consulta: 16 Agosto 2000].

Greek Jewellery - 5000 years of tradiction (s/data). Greek Jewellery - 5000 years of tradiction [em linha], p. 32.

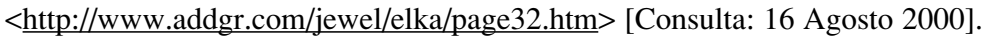




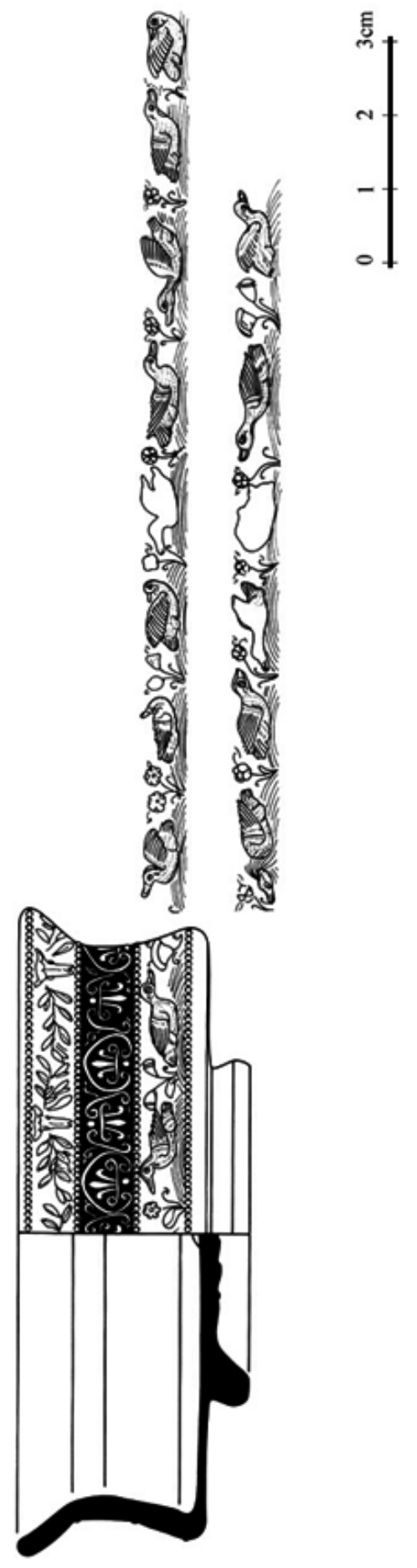

島 


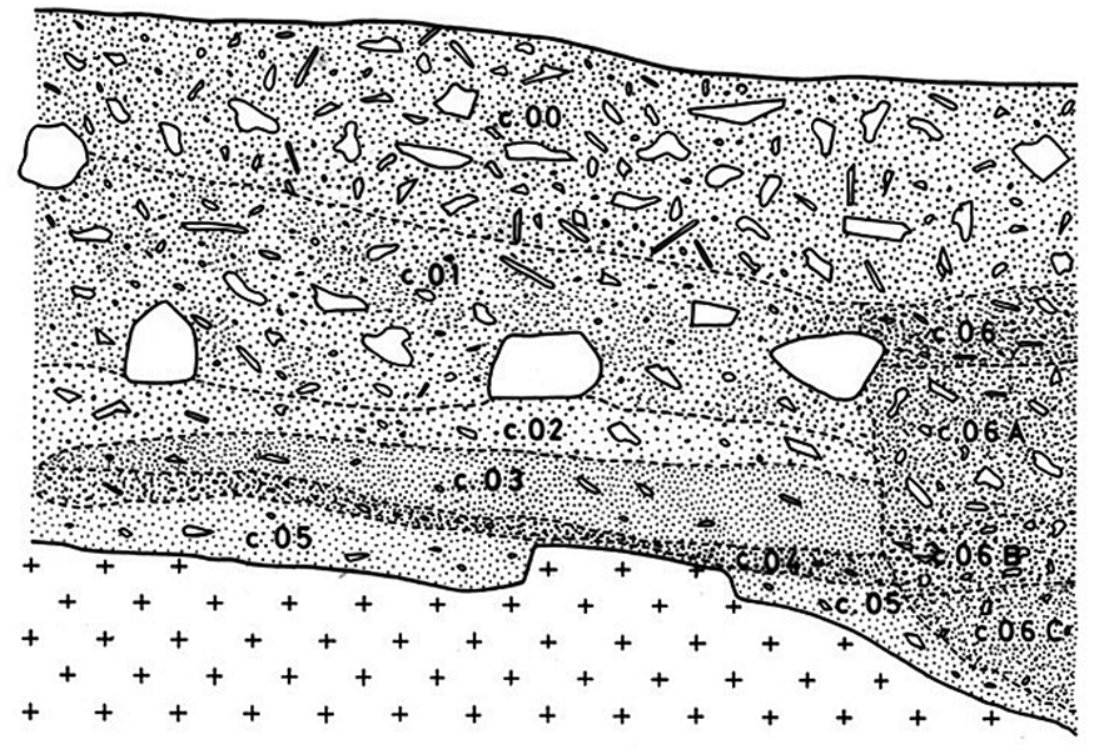

FIG. 2

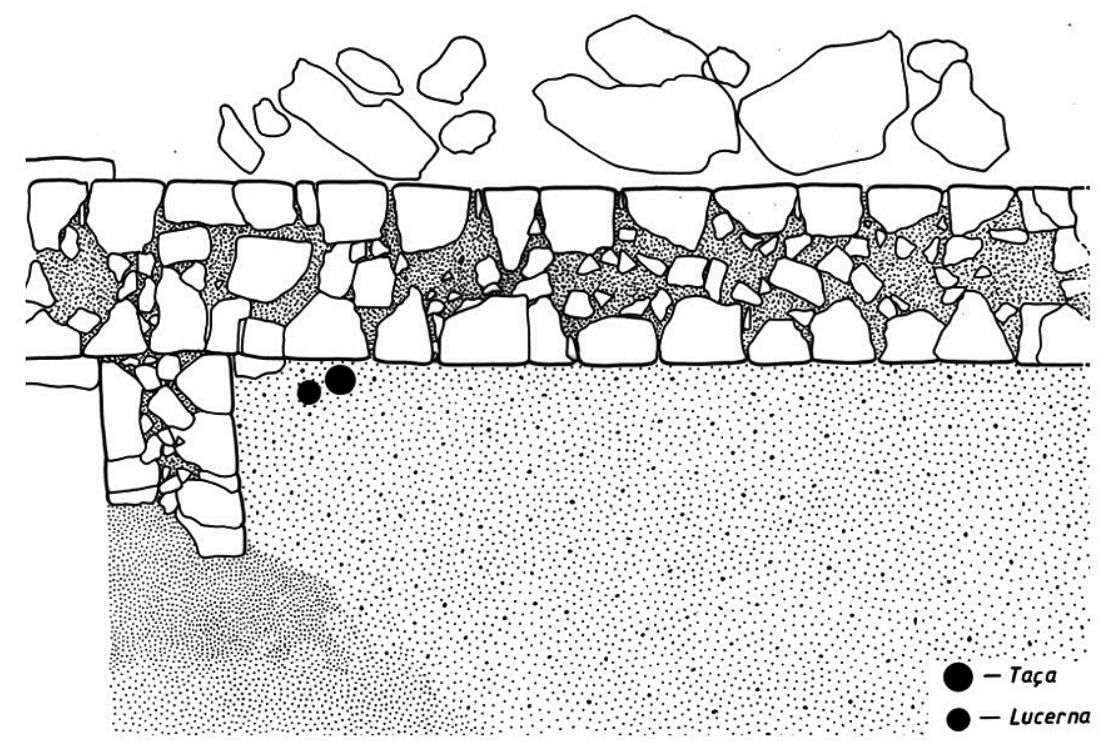

FIG. 3 

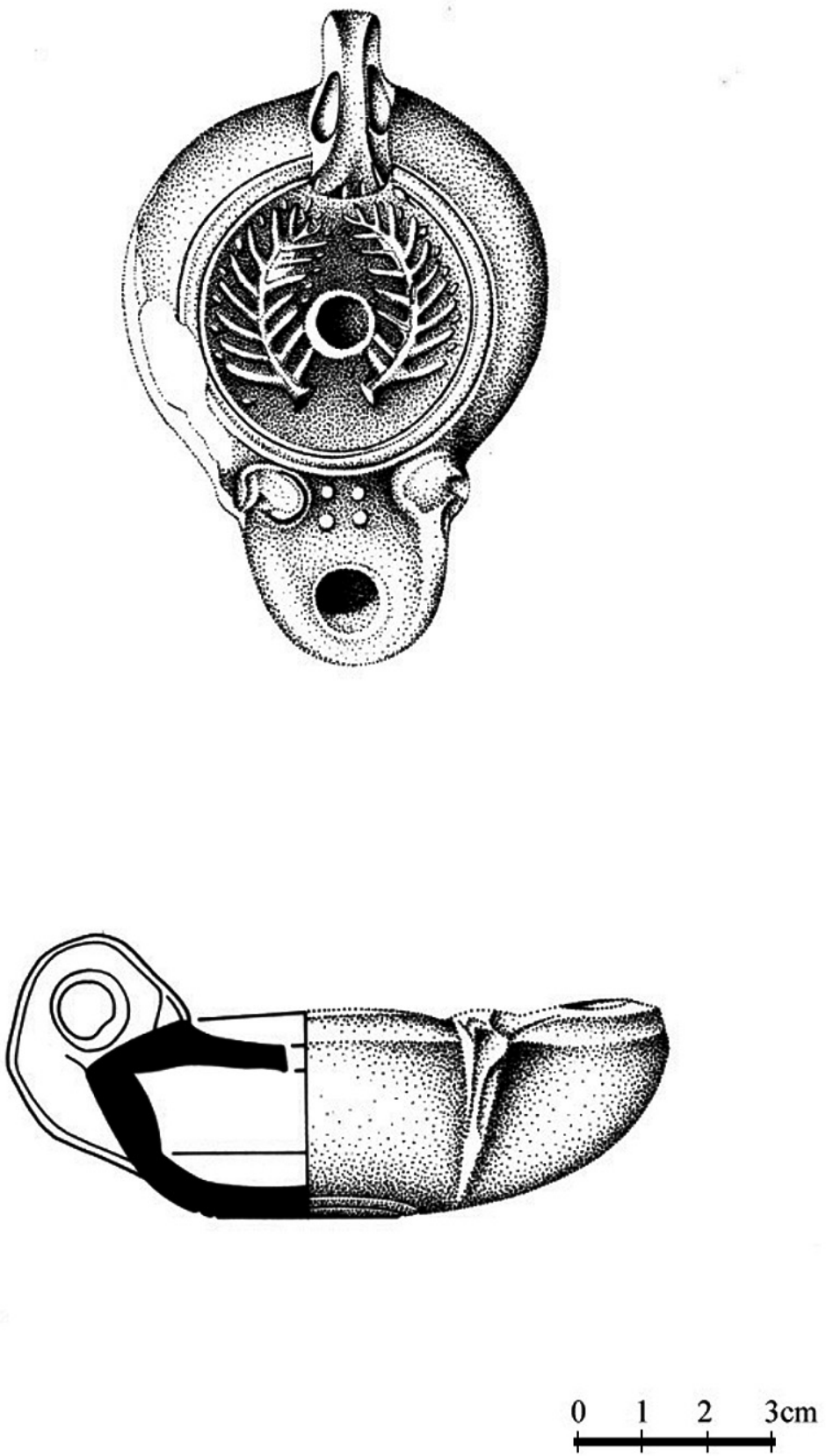

FIG. 4 


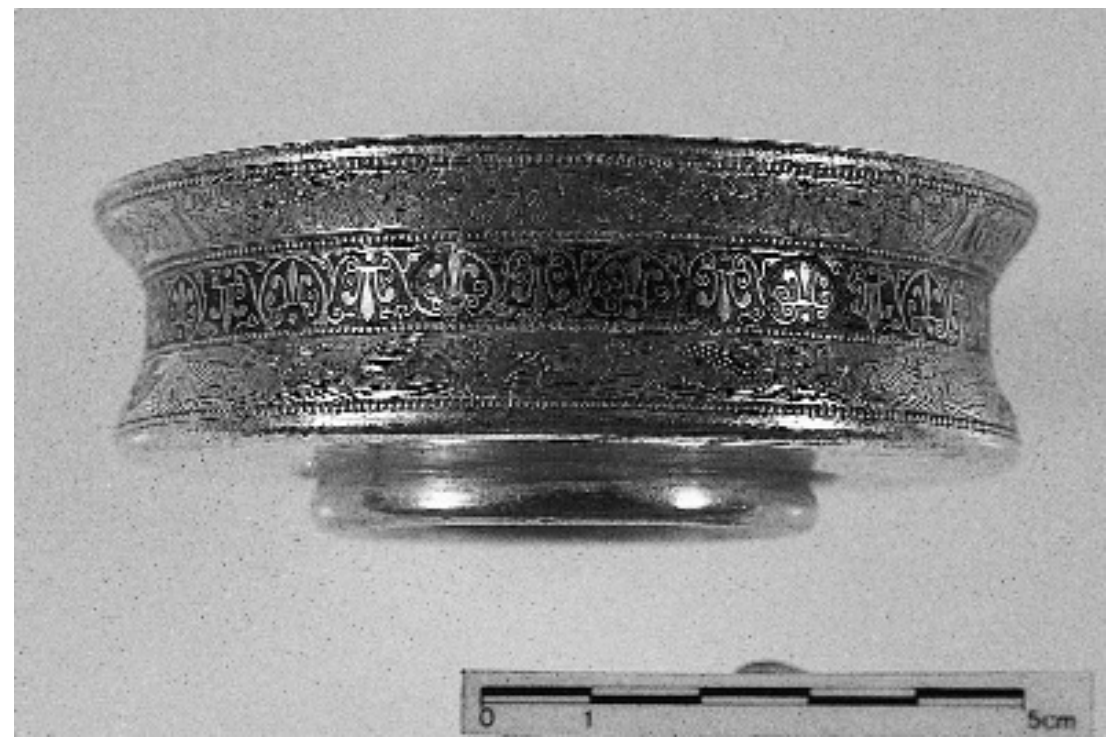

EsT. I-1

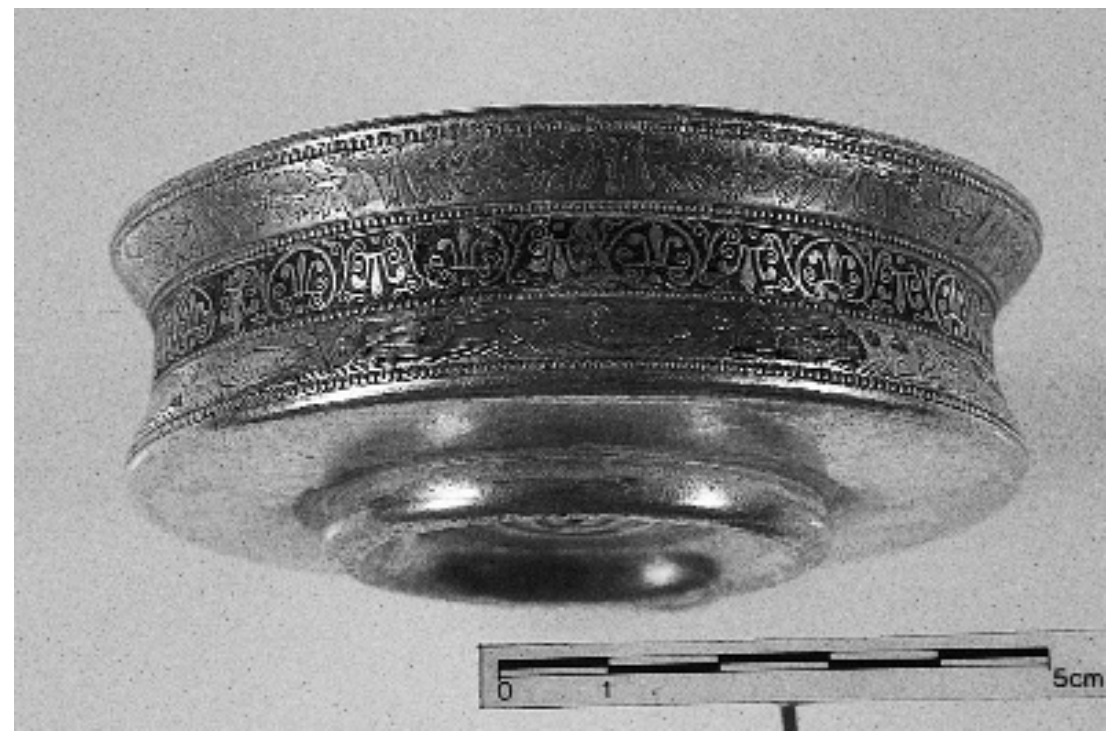

EsT. I-2 


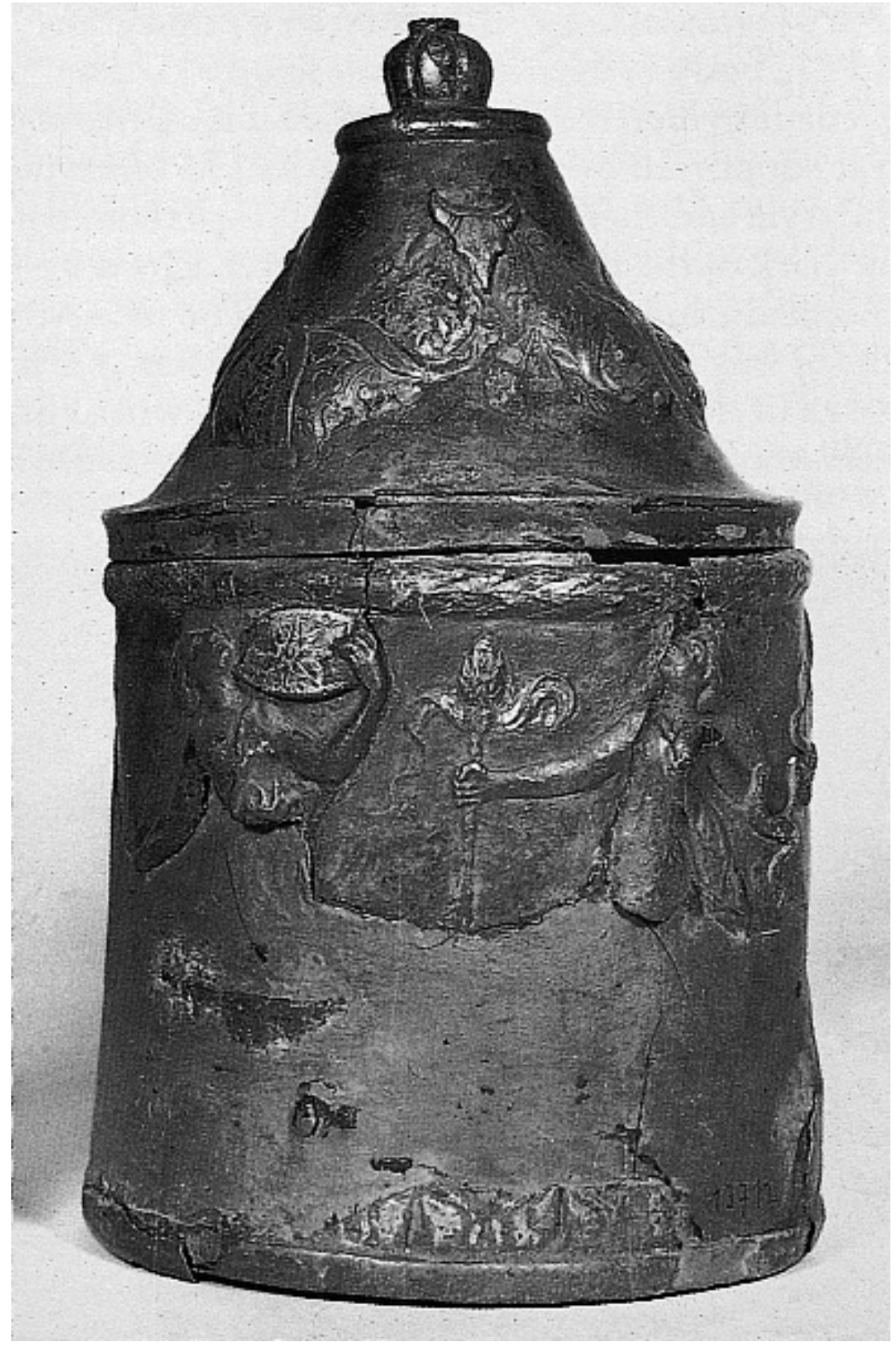

Est. II 


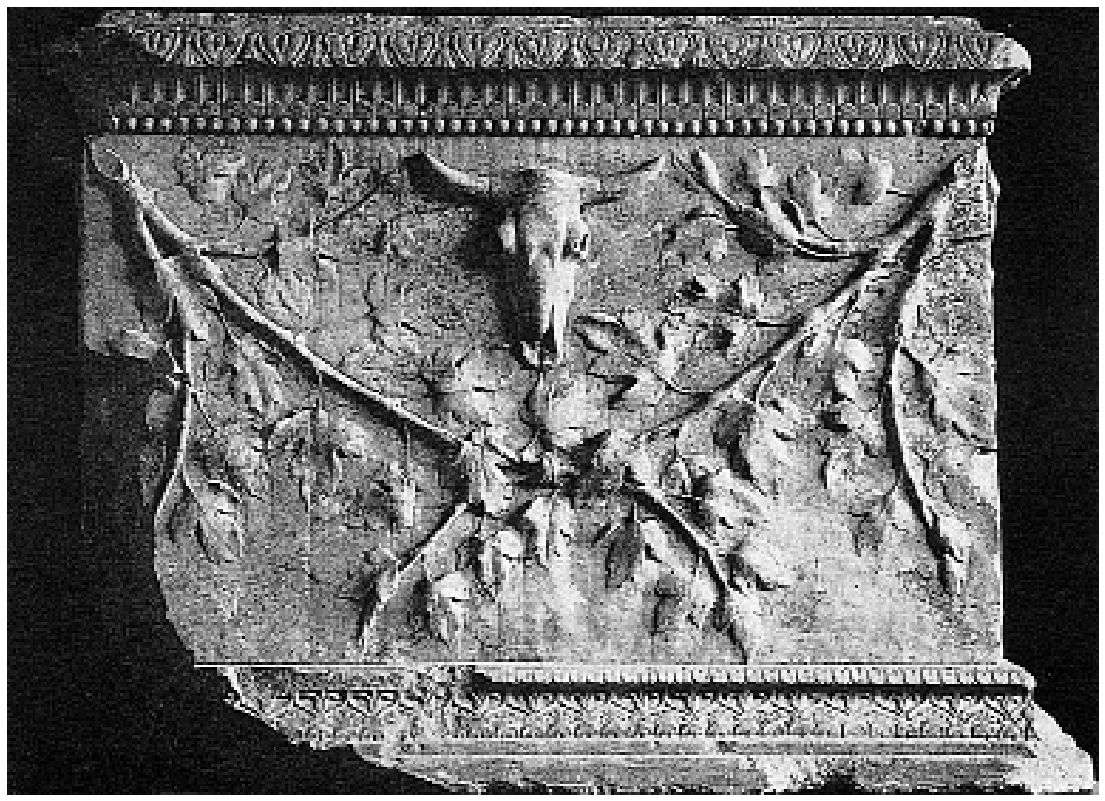

EsT. III-1

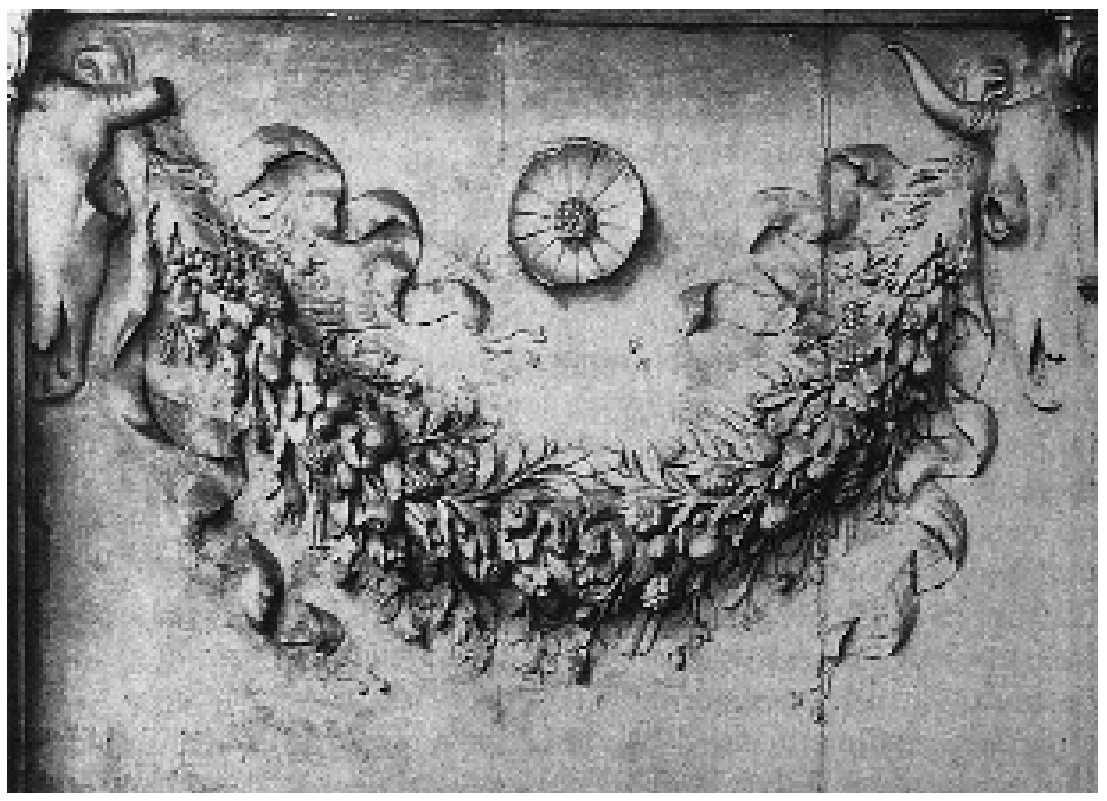

EST. III-2 


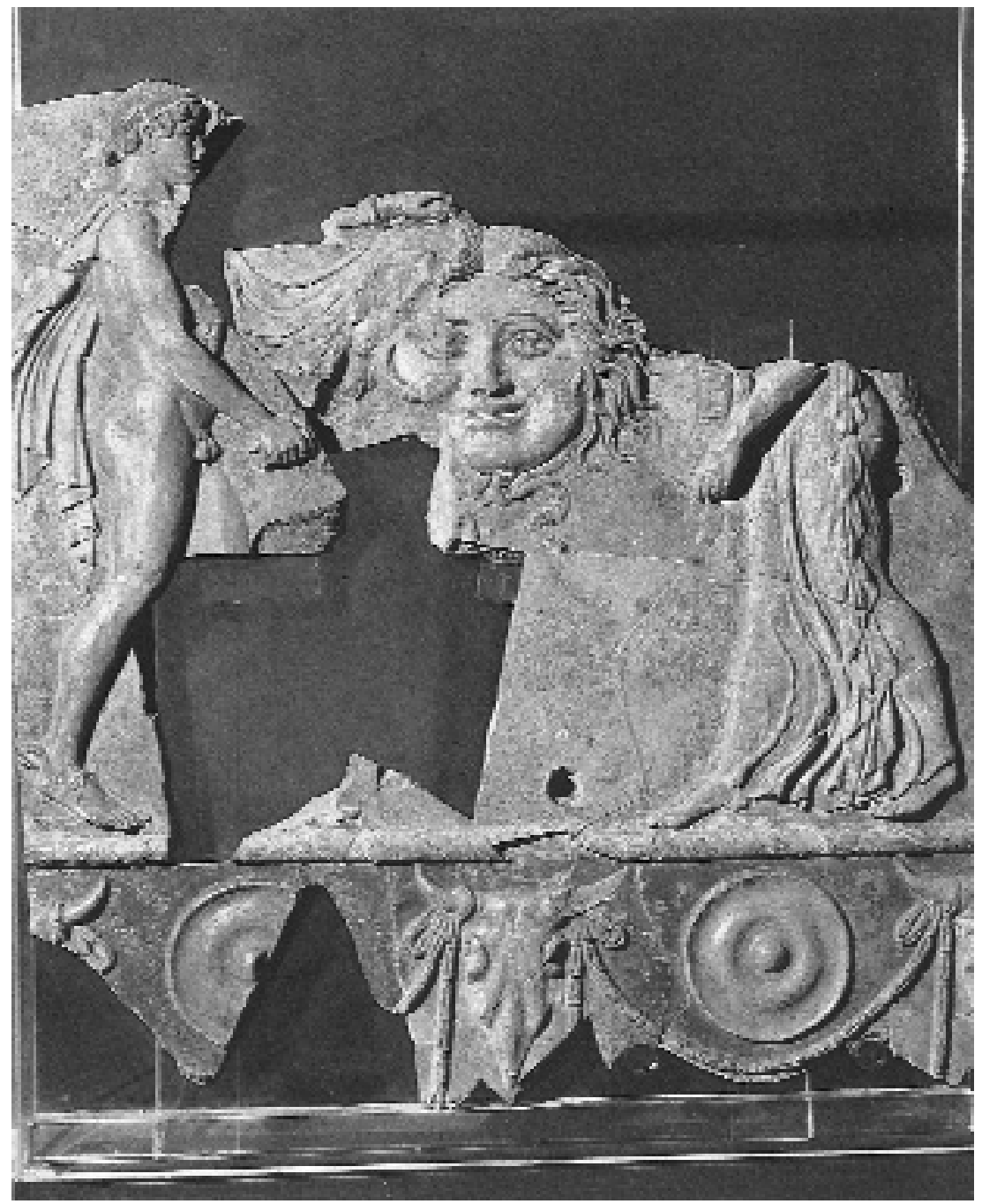

EsT. IV 


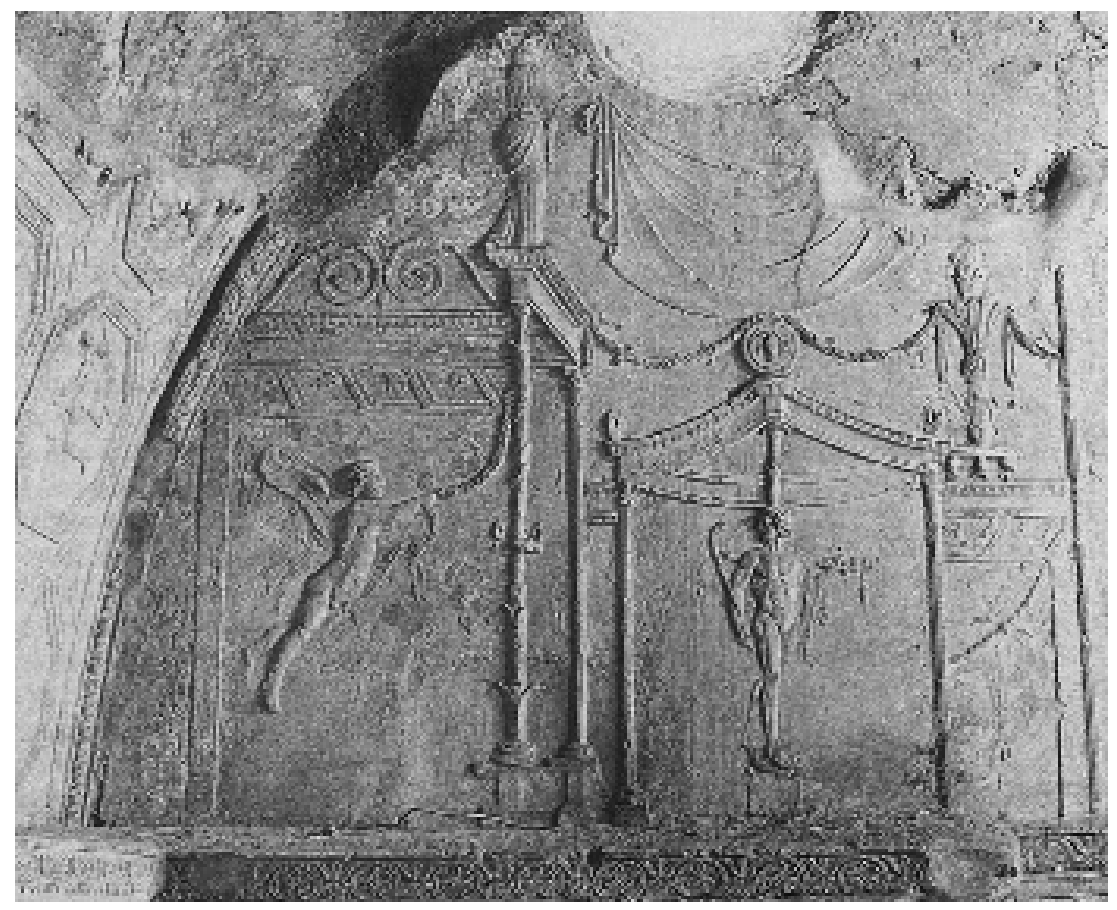

EsT. V 


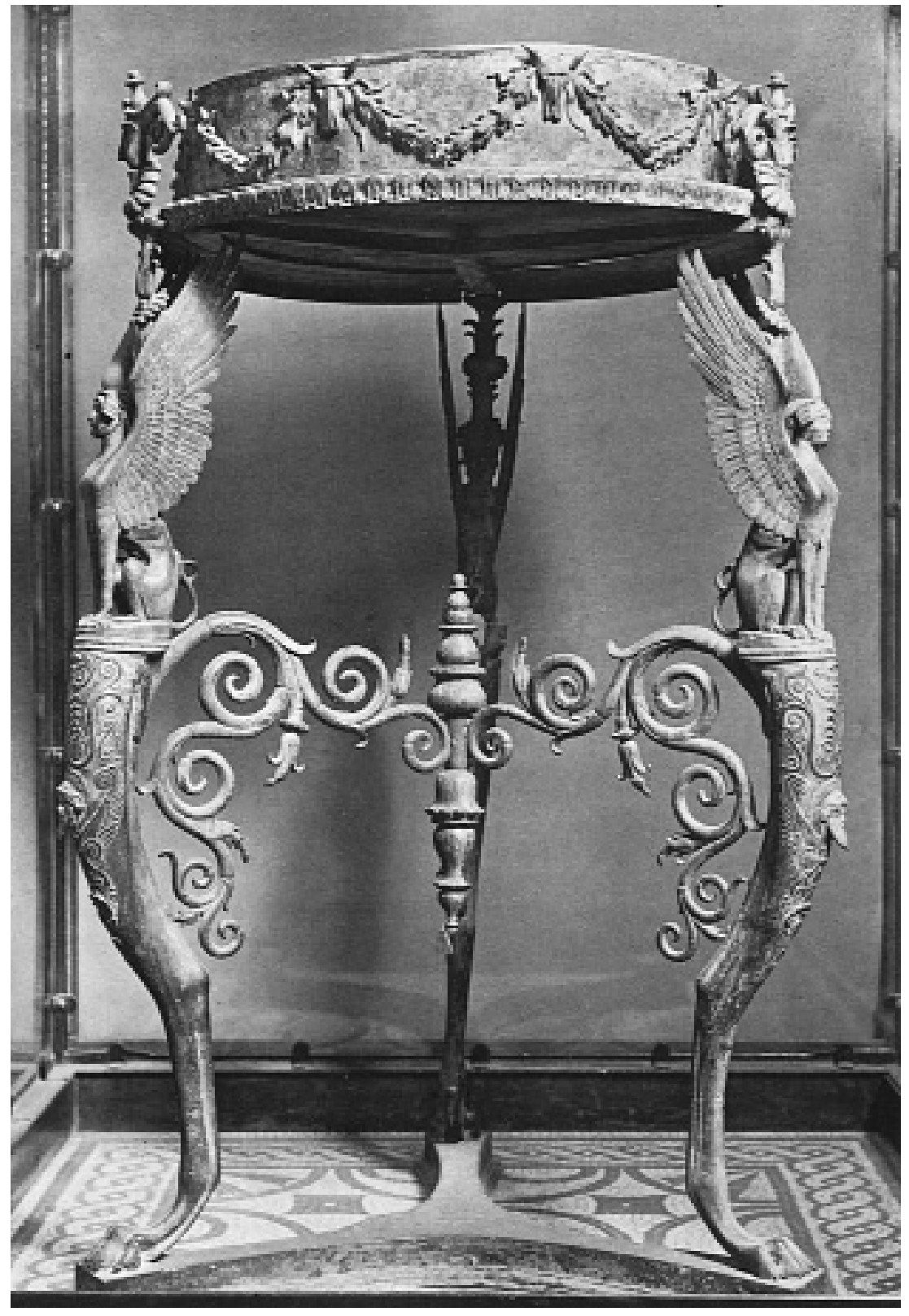

EST. VI 


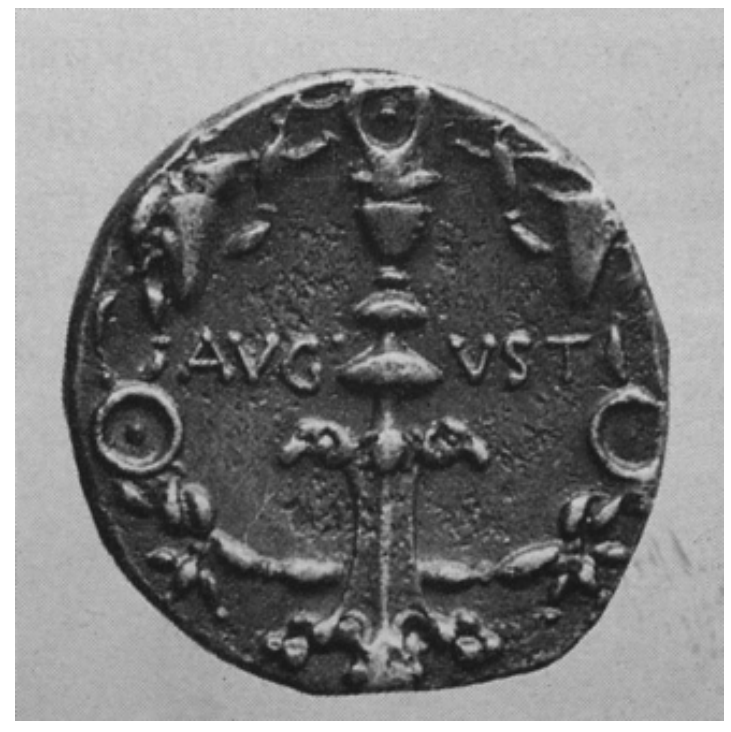

EsT. VII-1

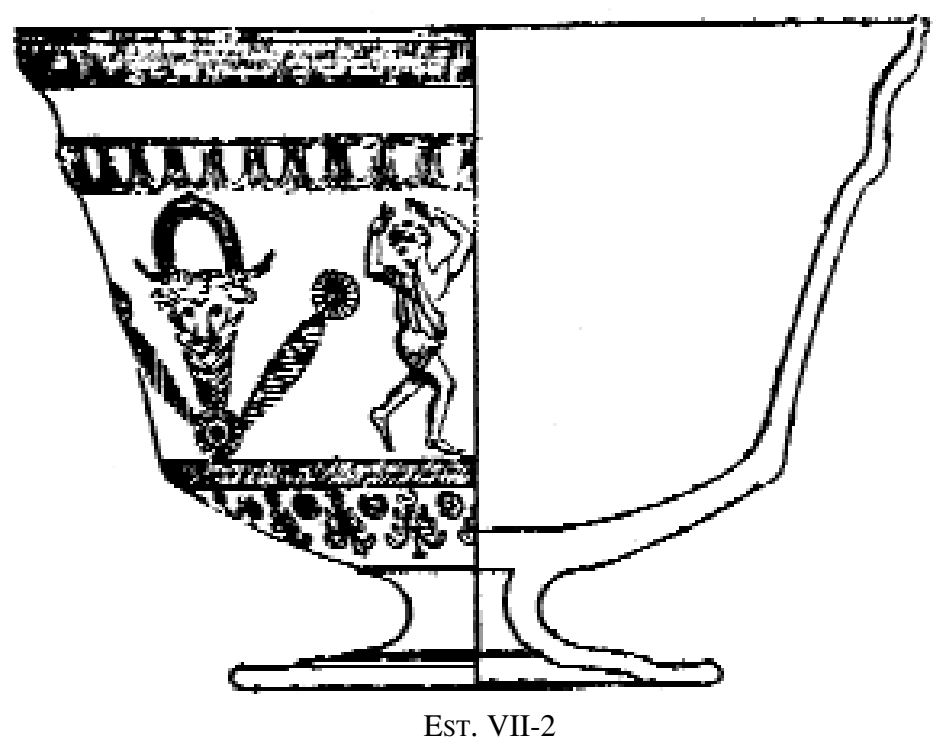




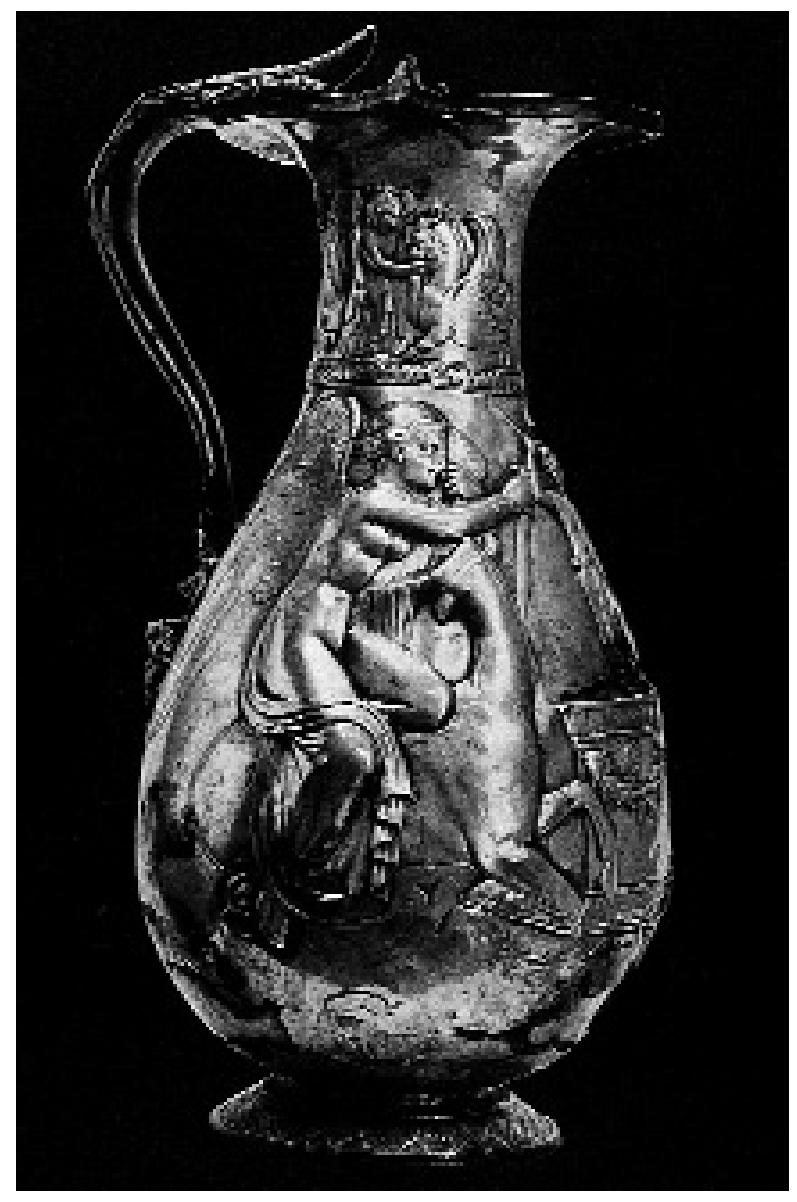

Est. VIII 


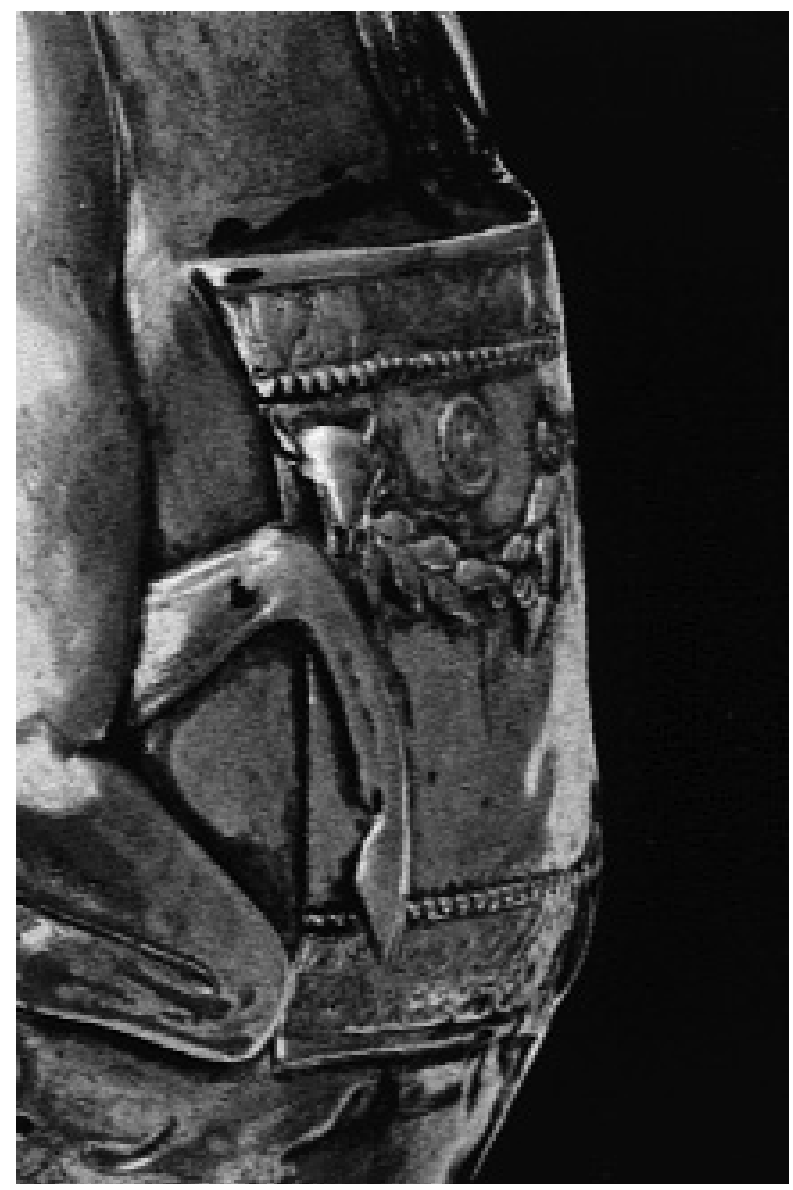

Est. IX 


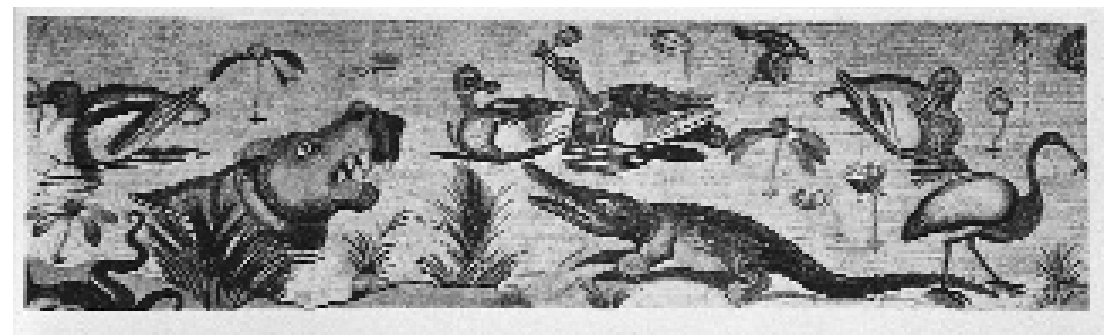

EsT. X-1

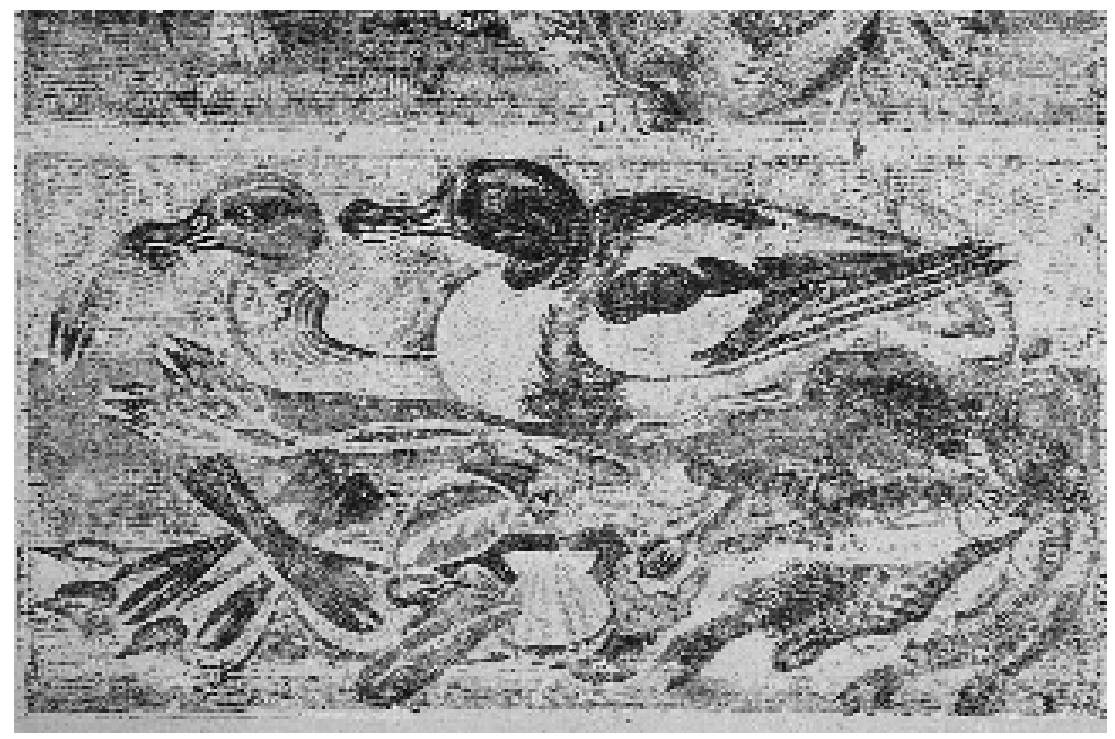

EsT. X-2 


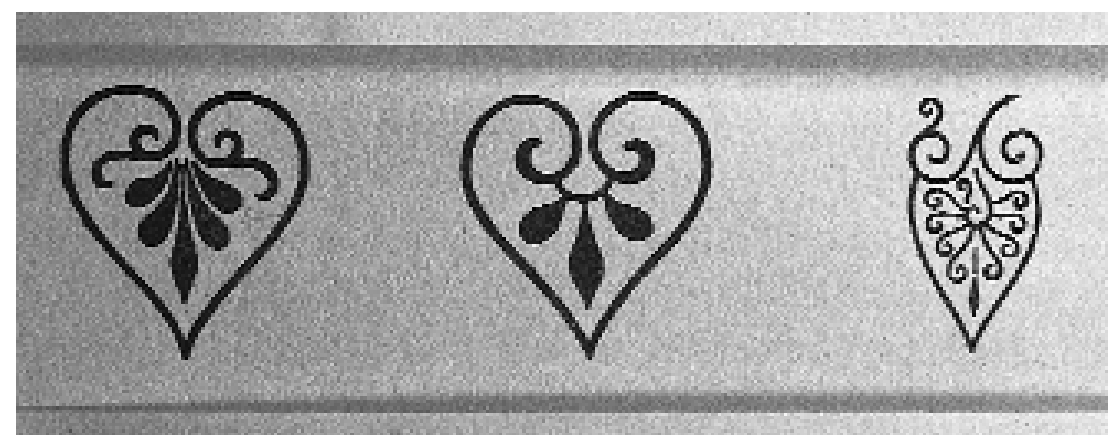

Est. XI-1

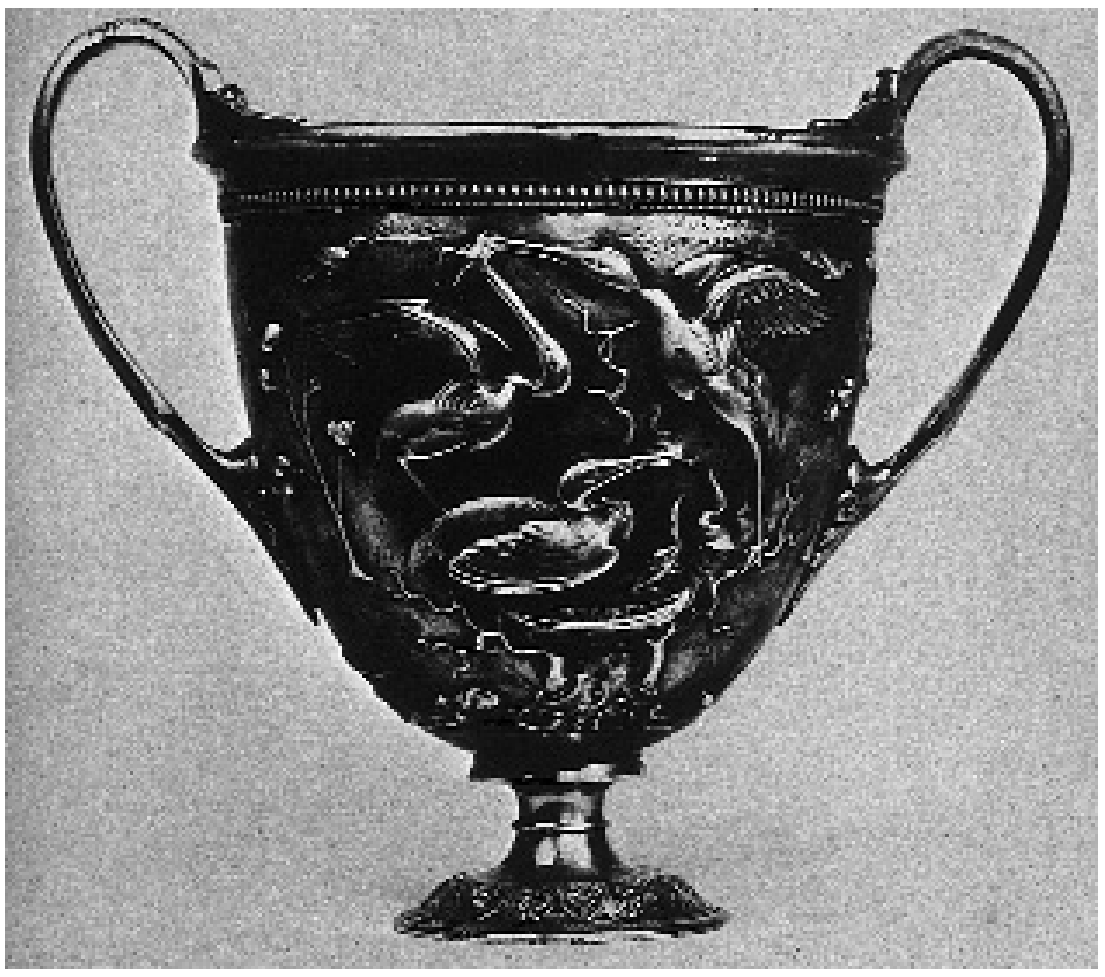

EsT. XI-2 


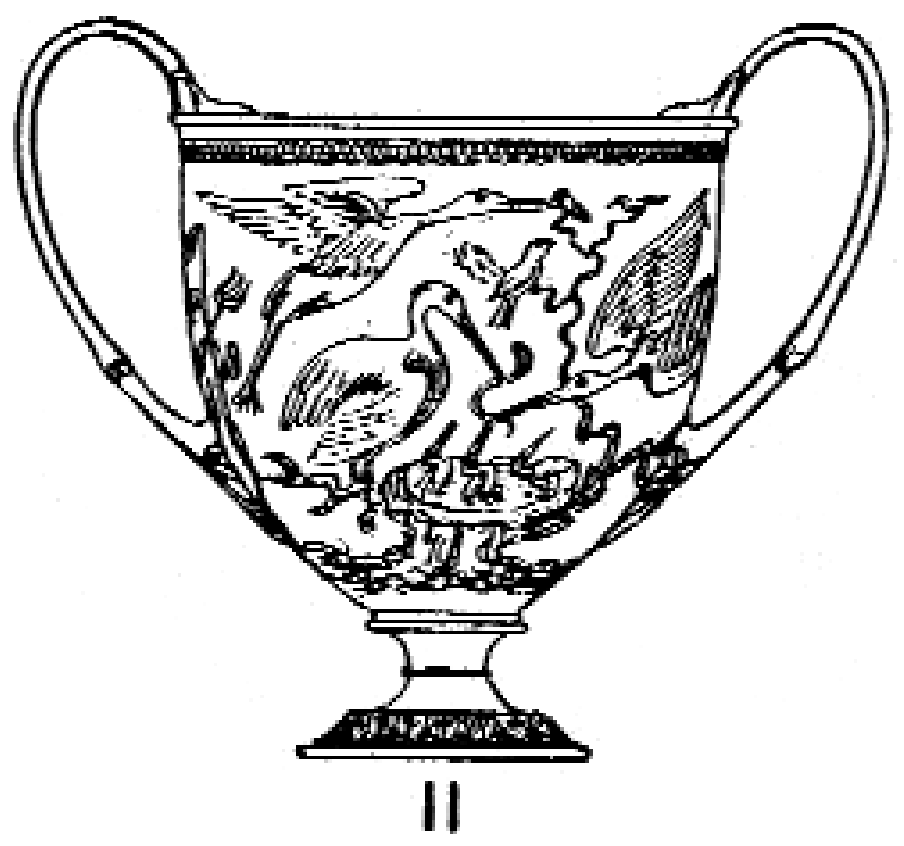

EsT. XII-1

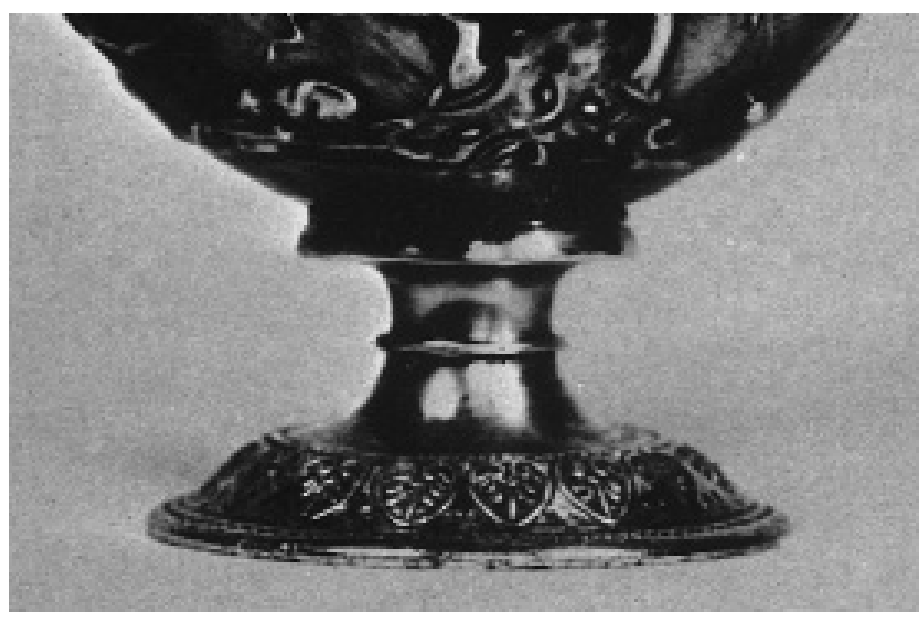

EST. XII-2 


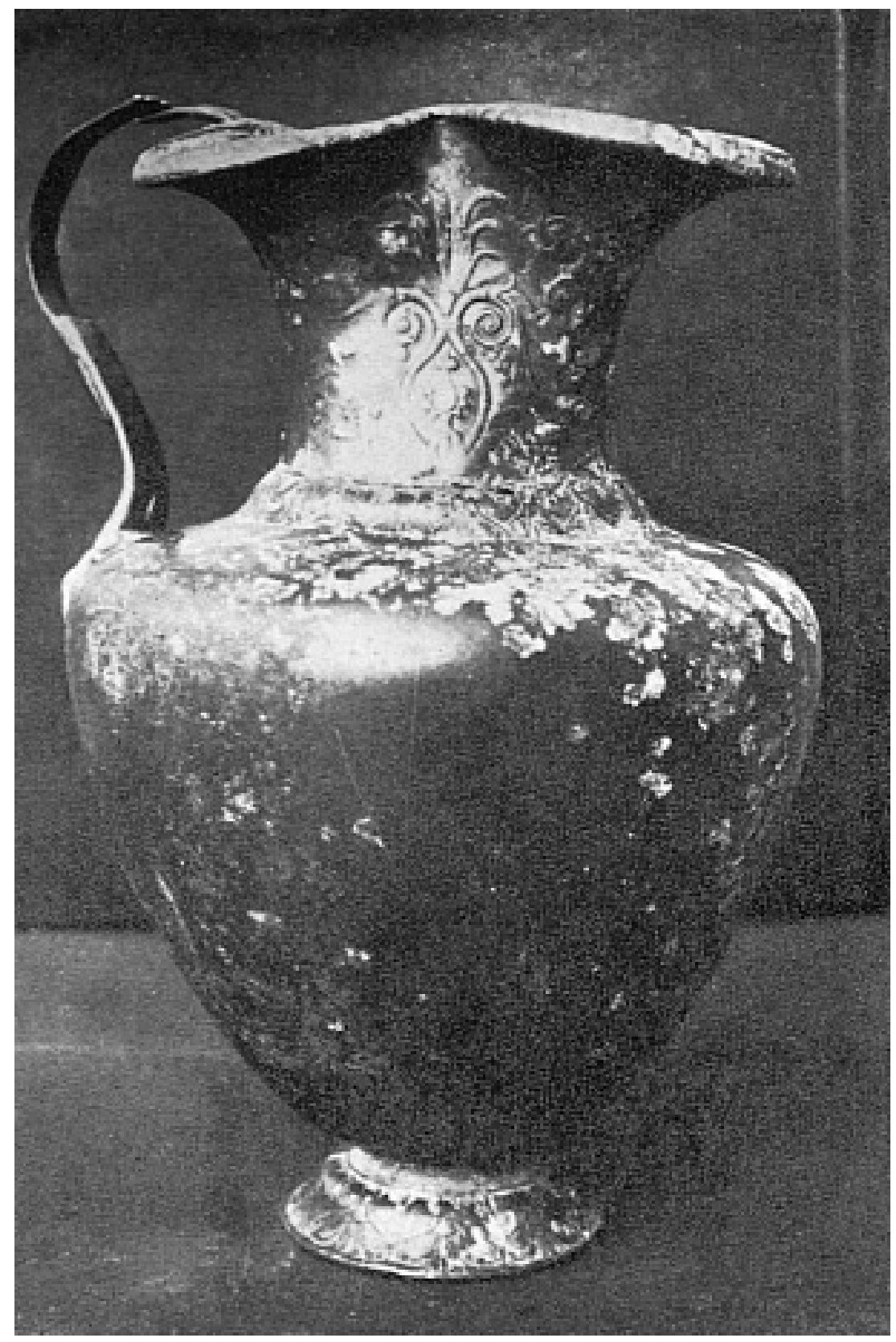

Est. XIII 


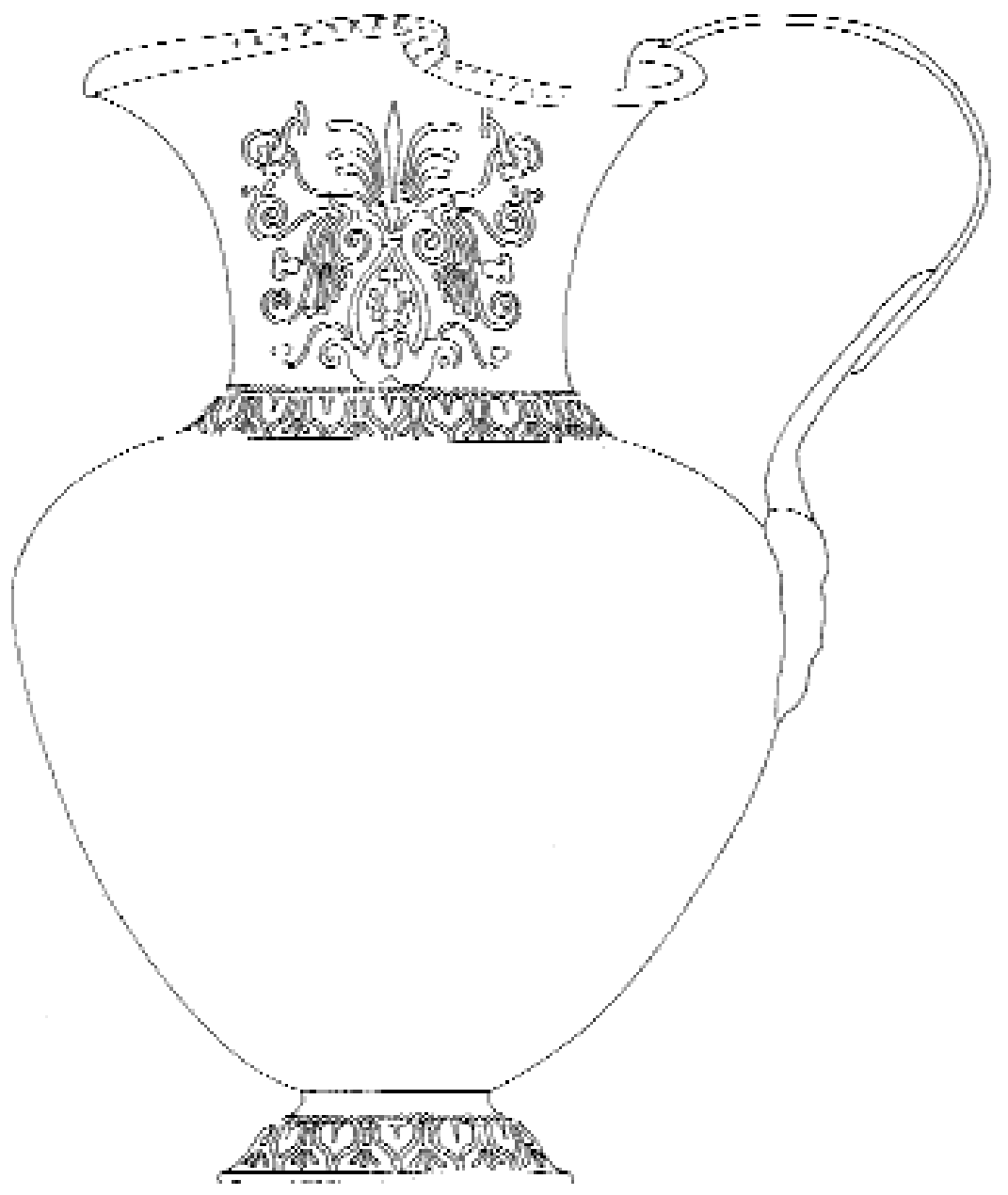

Est. XIV 


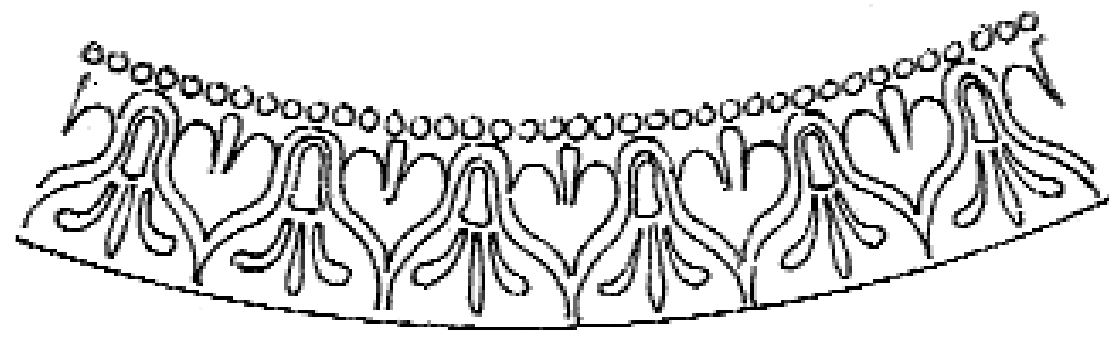

EsT. XV-1

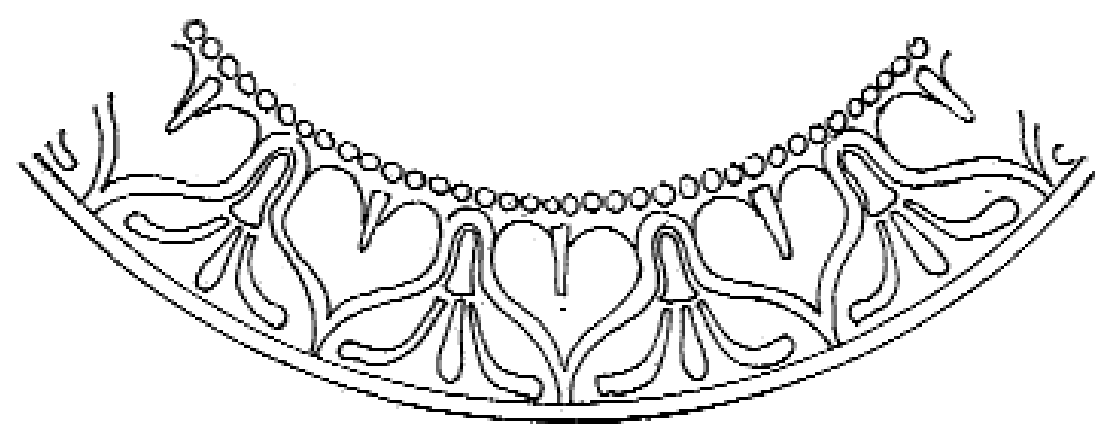

Est. XV-2 


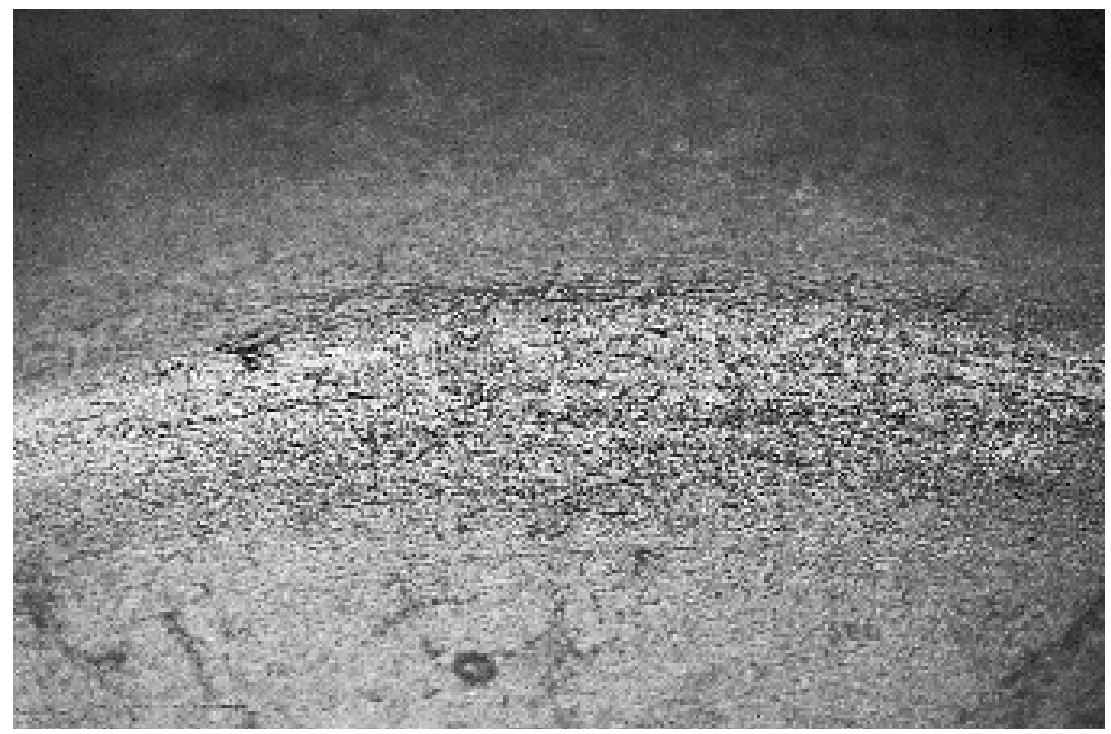

EsT. XVI-1

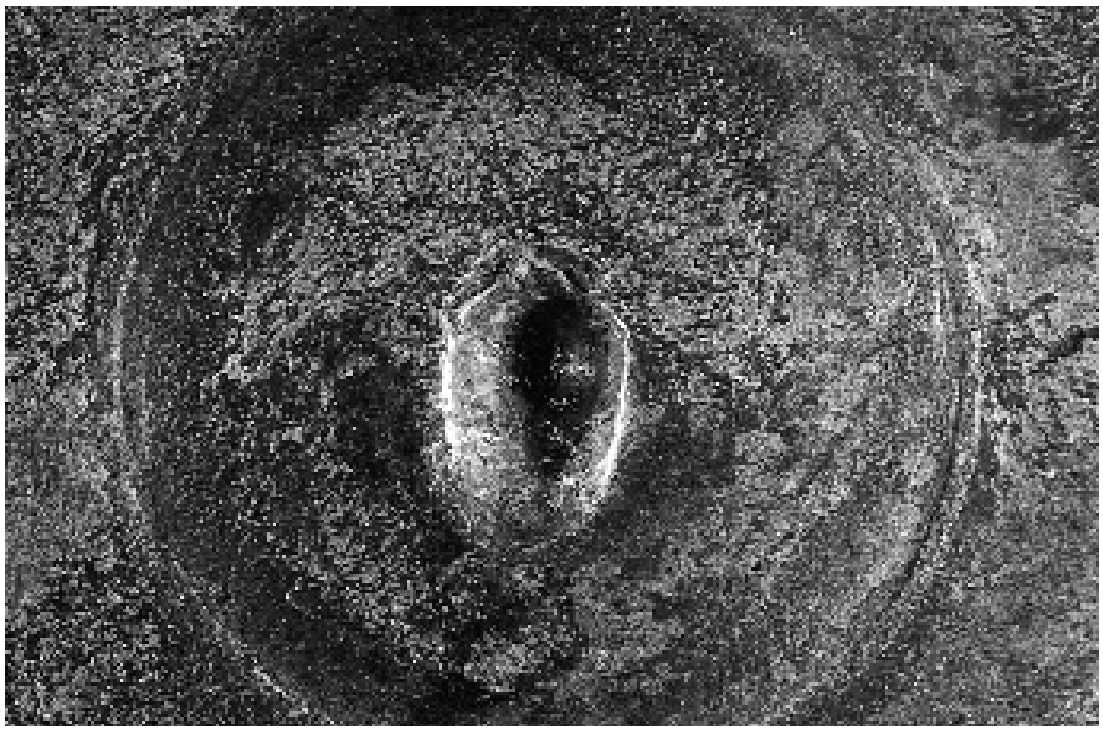

Est. XVI-2 


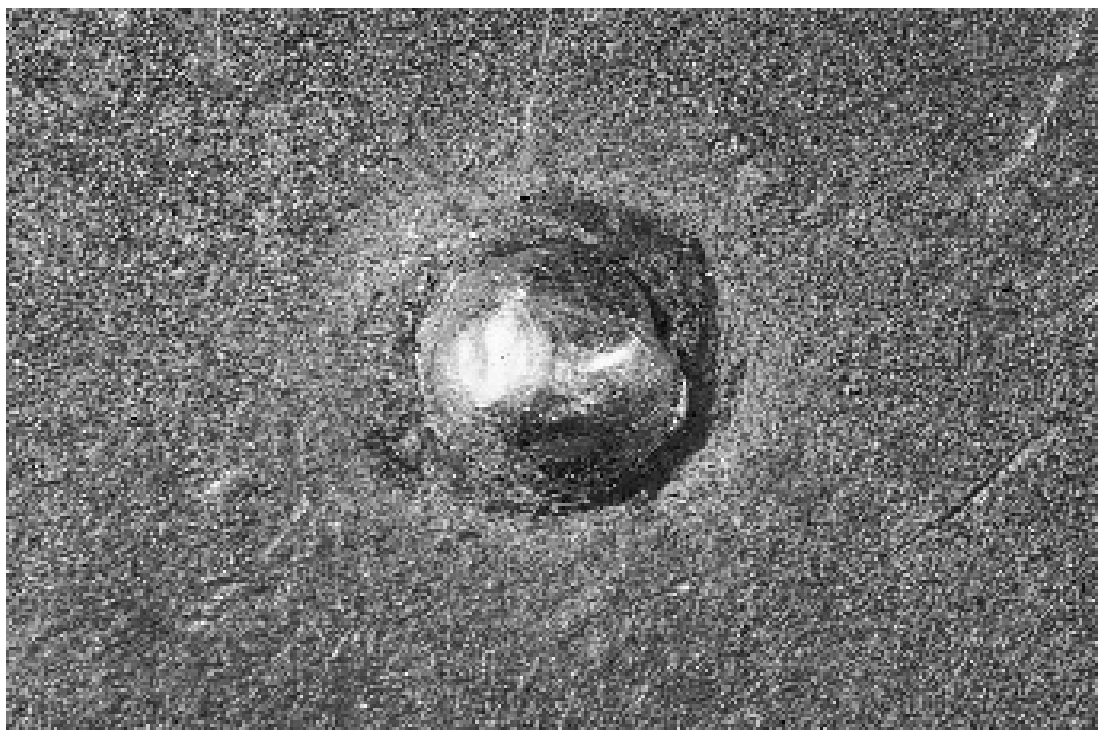

EsT. XVII-1

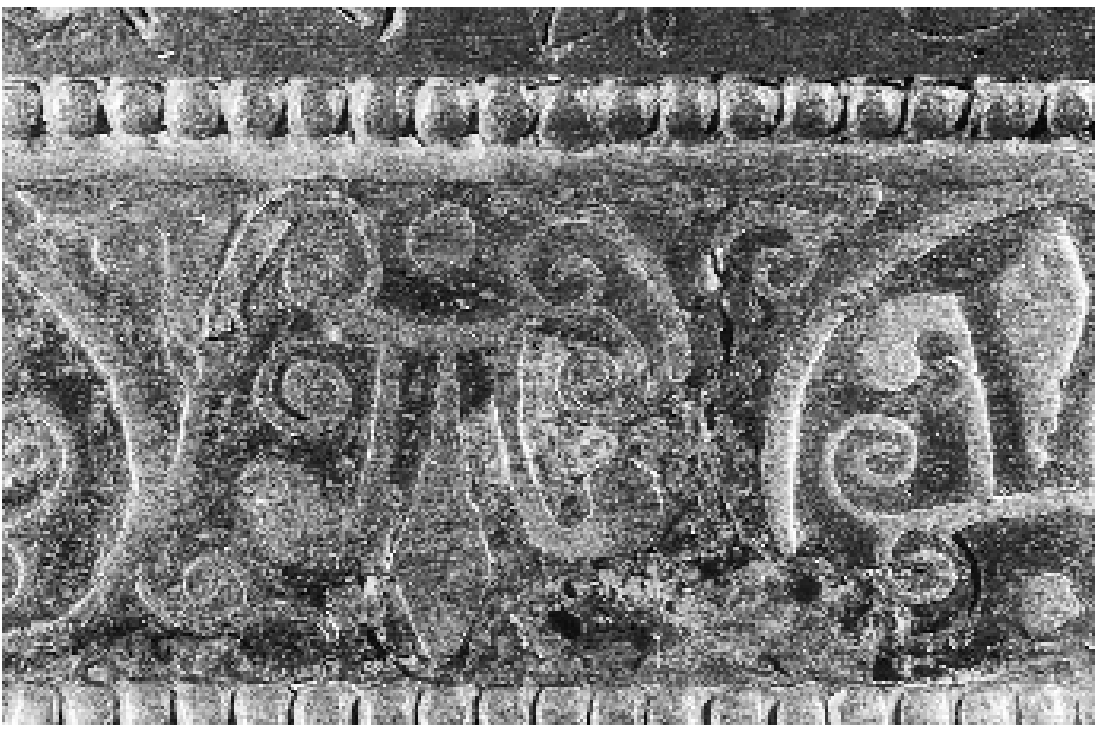

EsT. XVII-2 


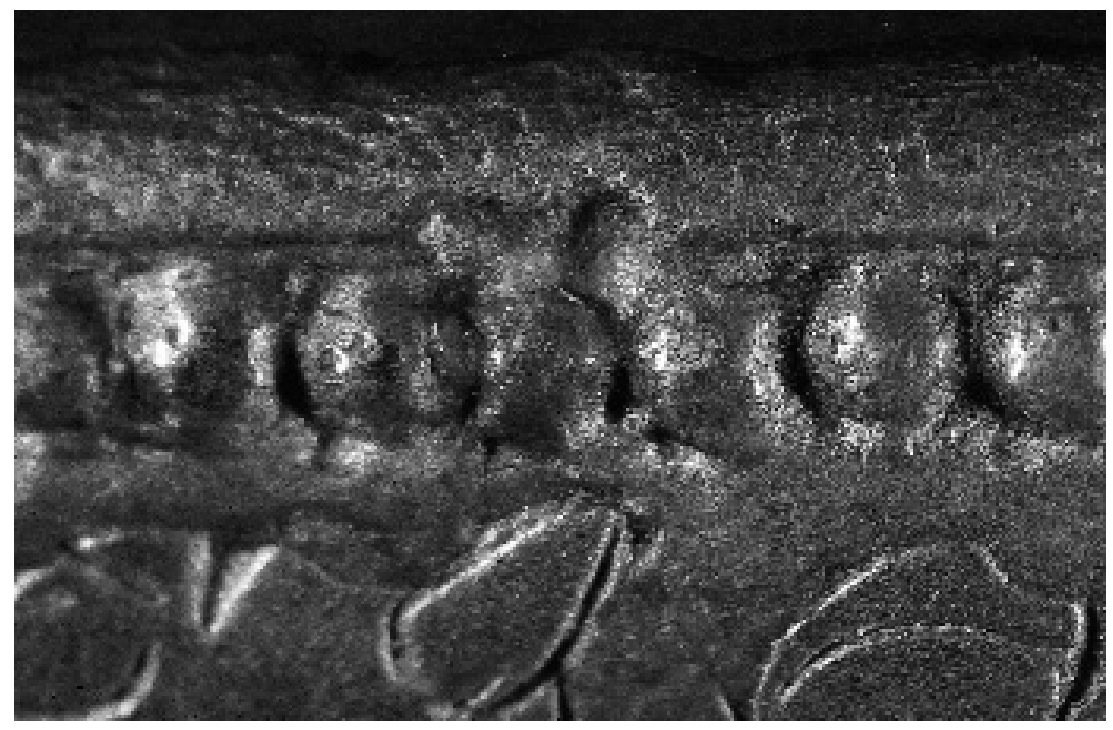

Est. XVIII-1

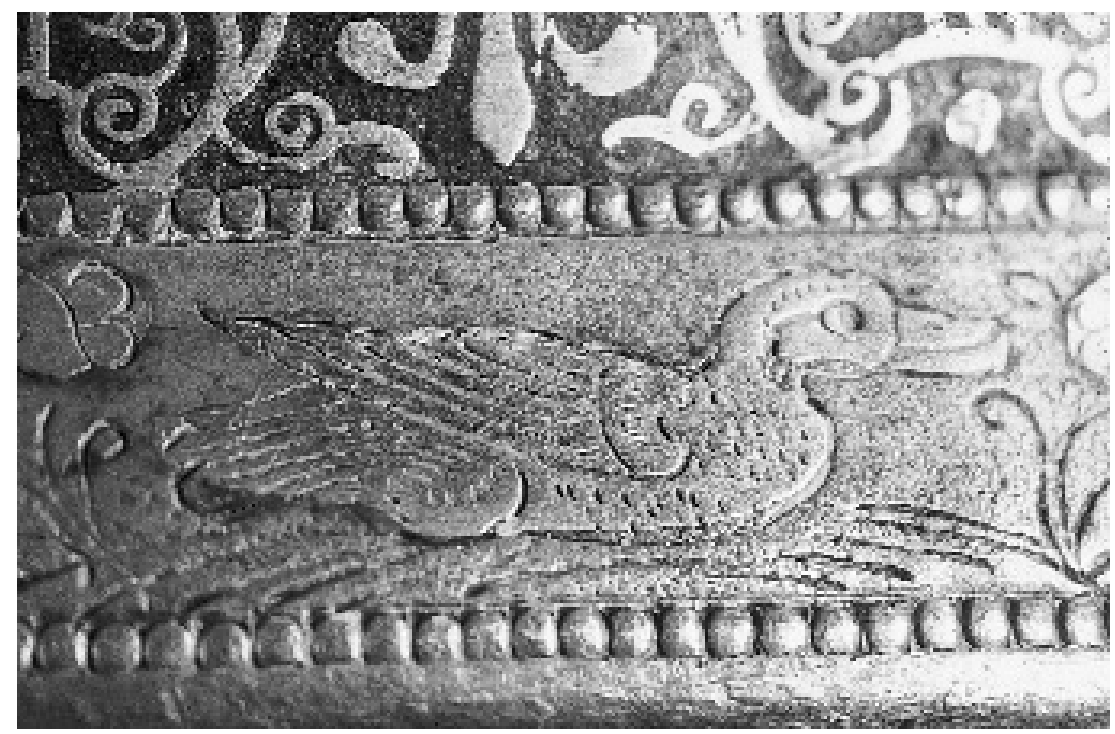

Est. XVIII-2 
Fon

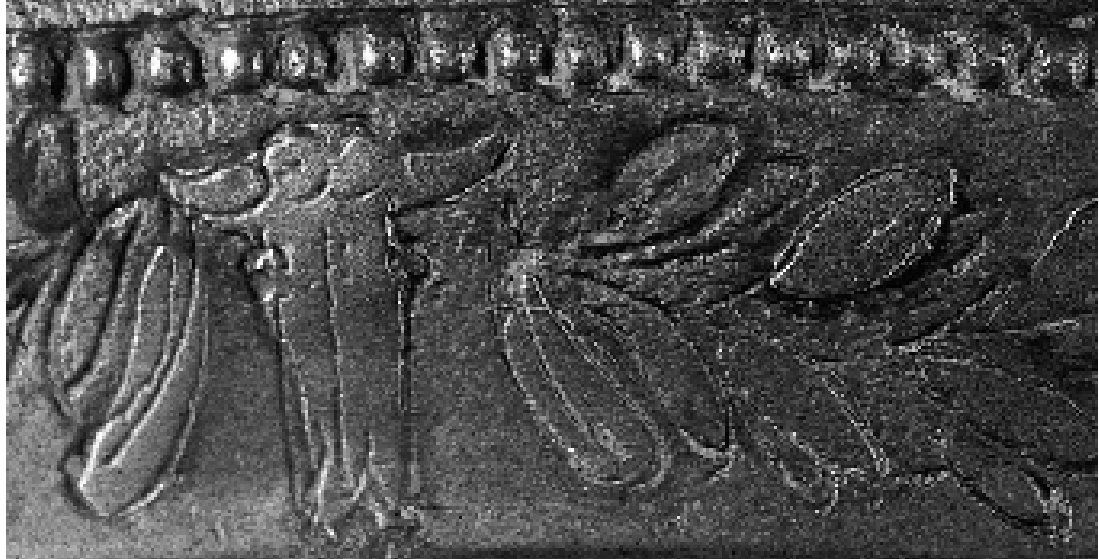

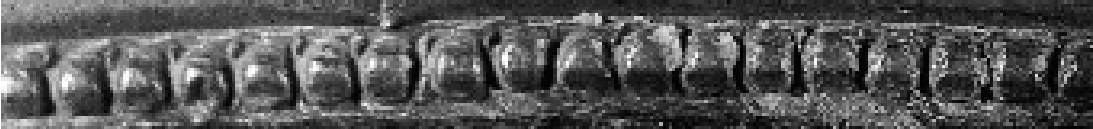

EsT. XIX-1

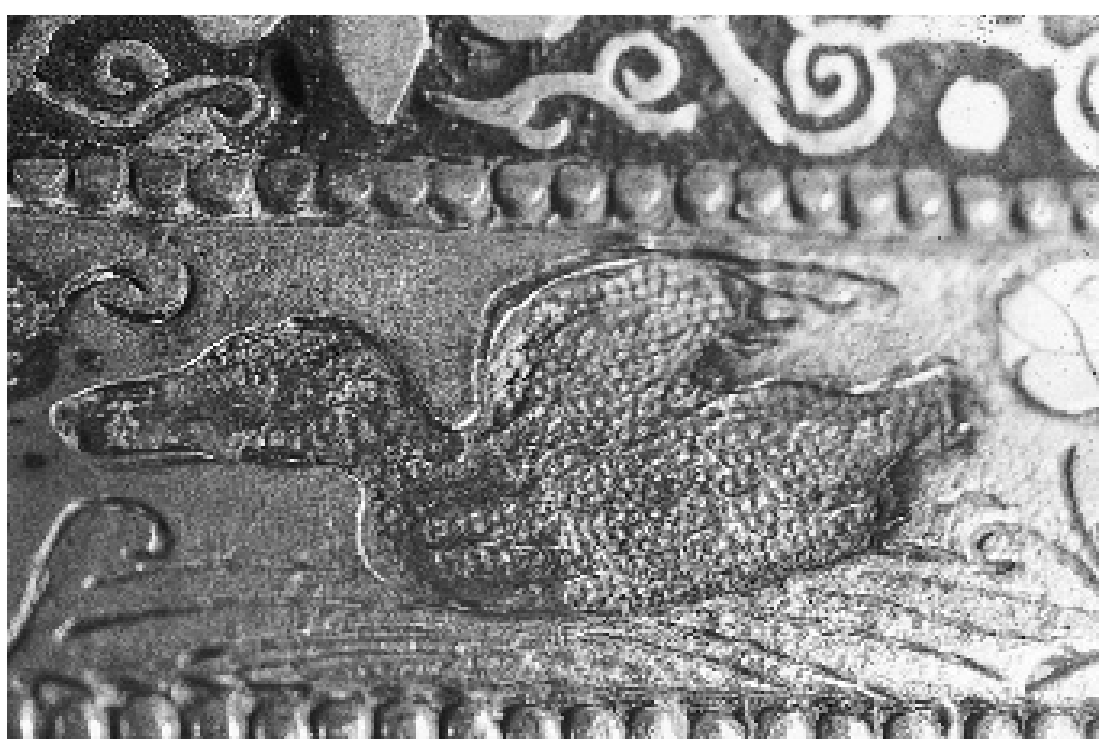

Est. XIX-2 


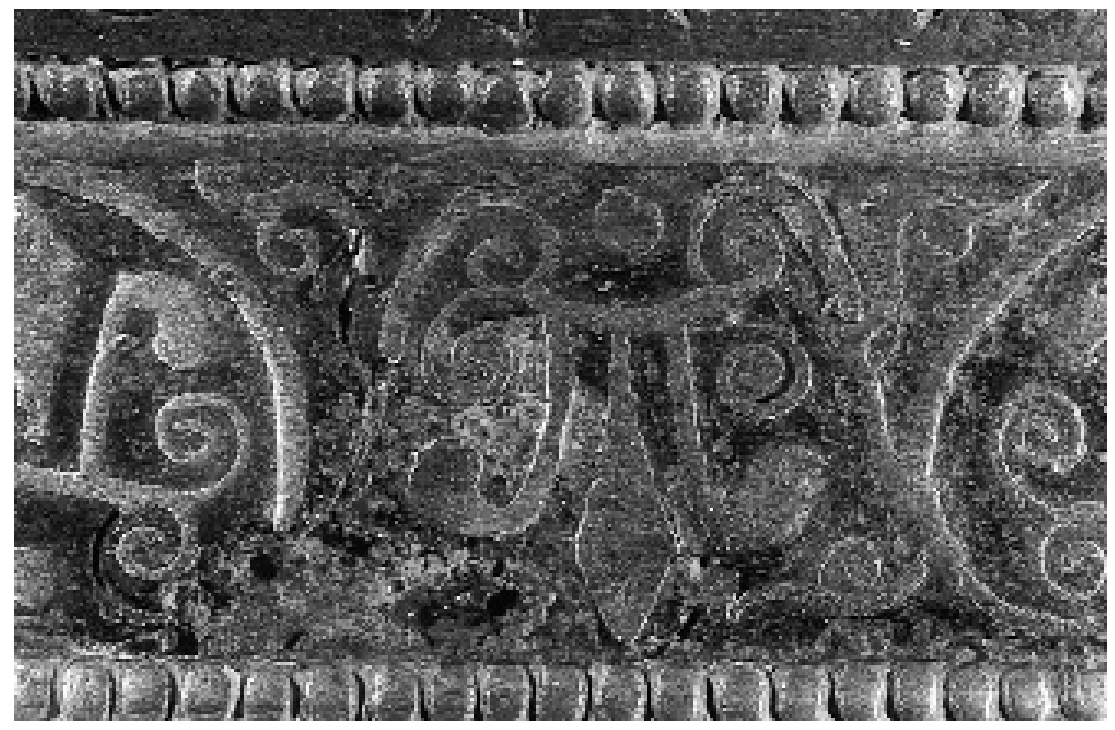

EsT. XX-1

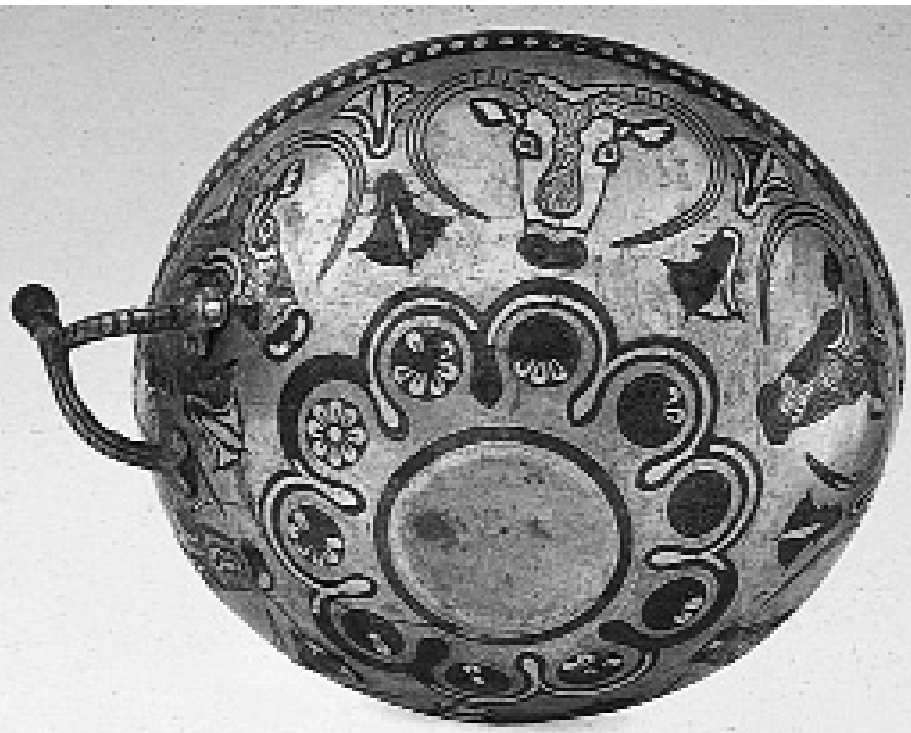

Est. XX-2 


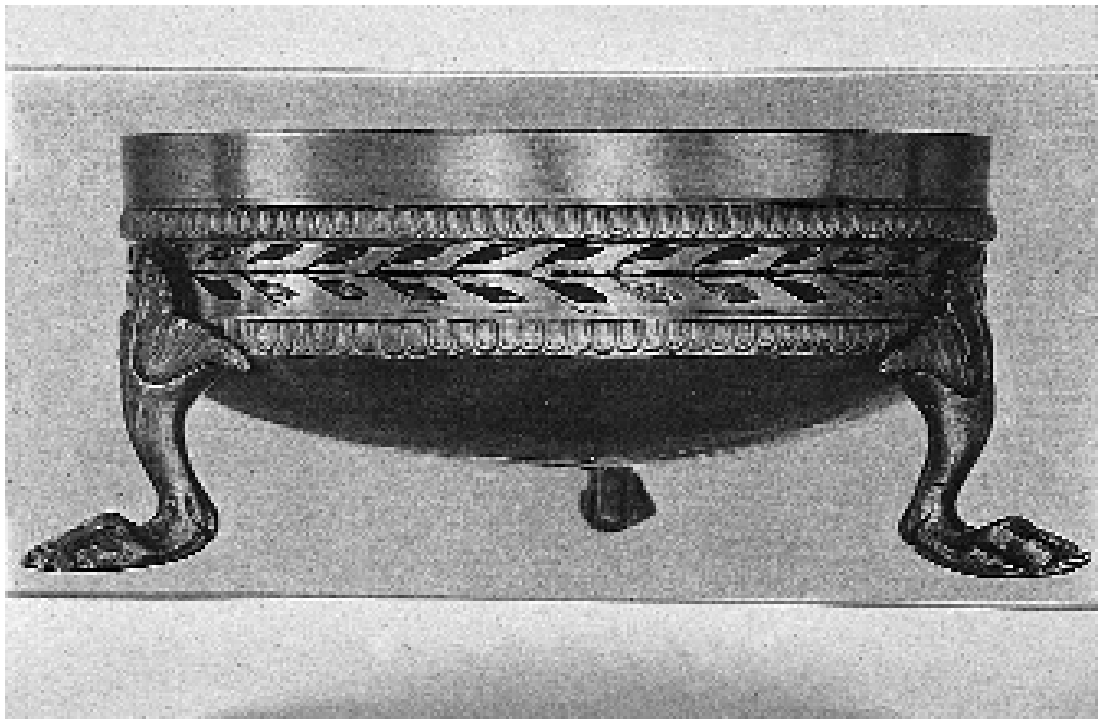

Est. XXI-1

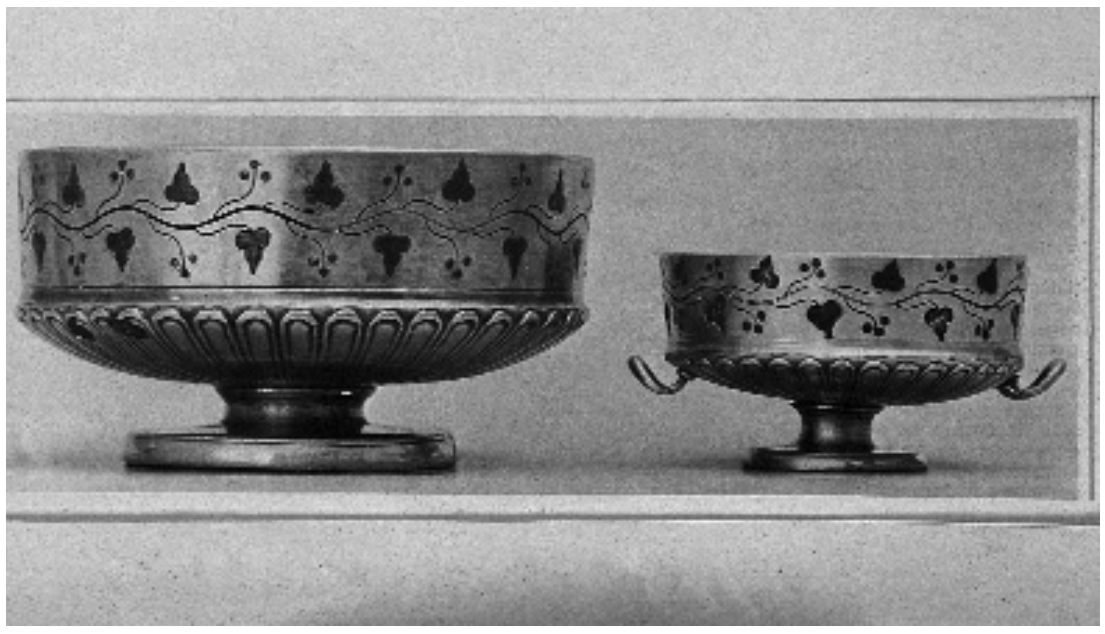

Est. XXI-2 